\title{
Postcollisional High-Grade Metamorphism, Orogenic Collapse, and Differential Cooling of the East African Orogen of Northeast Mozambique
}

\author{
Kosuke Ueda, ${ }^{1, \star}$ Joachim Jacobs, ${ }^{1}$ Robert James Thomas, ${ }^{2}$ Jan Kosler, ${ }^{1}$ \\ Matt S. A. Horstwood, ${ }^{2,3}$ Jo-Anne Wartho, ${ }^{4}$ Fred Jourdan, ${ }^{5}$ \\ Benjamin Emmel, ${ }^{1}$ and Rogerio Matola ${ }^{6}$
}

1. Department of Earth Science, University of Bergen, Allégaten 41, 5007 Bergen, Norway; 2. British Geological Survey, Nicker Hill, Keyworth, Nottingham NG12 5GG, United Kingdom; 3. Natural Environment Research Council Isotope Geosciences Laboratory, British Geological Survey, Nicker Hill, Keyworth, Nottingham NG12 5GG, United Kingdom; 4. School of Earth and Space Exploration, Arizona State University, P.O. Box 871404, Tempe, Arizona 85287, U.S.A.; 5. Western Australian Argon Isotope Facility, John de Laeter Centre for Mass Spectrometry, and Department of Applied Geology, Curtin University, G.P.O. Box U1987, Perth, Western Australia 6845, Australia; 6. Direcção Nacional de Geologia (DNG), Maputo, Mozambique

\begin{abstract}
A B S T R A C T
The postcollisional tectonic development of northeast Mozambique and subsequent cooling from high-temperature metamorphism is delineated with an extensive new set of U-Pb titanite, ${ }^{40} \mathrm{Ar} /{ }^{39} \mathrm{Ar}$ hornblende, and ${ }^{40} \mathrm{Ar} /{ }^{39} \mathrm{Ar}$ mica analyses. The complex data suggest a polyphase metamorphic history from the late Neoproterozoic to the Ordovician within the East African-Antarctic Orogen (EAAO), with marked differences between the major constituent blocks. In all the data sets, samples from the basement south of the Lúrio Belt show generally younger ages than those from the north, resulting from a late metamorphic event and slow cooling between ca. 520 and $440 \mathrm{Ma}$. The ages north and south of the Lúrio Belt are consistently offset by ca. 30-70 Ma, a difference that is maintained and even appears to increase during cooling from very high temperatures to ca. $350^{\circ} \mathrm{C}$. Based on the first-order assumption that all the ages are cooling ages, cooling rates in the south are estimated at ca. $7^{\circ}-8^{\circ} \mathrm{C} / \mathrm{Ma}$, while those north of the Lúrio Belt are faster at ca. $16^{\circ} \mathrm{C} / \mathrm{Ma}$. The data are consistent with previous geochronological, petrographic, and field data and suggest a late high-temperature/low-pressure metamorphic event that affected only the basement rocks south of the Lúrio Belt and portions of the latter. This late metamorphism and subsequent delayed, slower cooling agree well with a model of elevated heat flow following lithosphere delamination in the southern part of the orogen, which also explains the observed widespread granitoid magmatism, migmatization, and renewed deformation in the southern basement.
\end{abstract}

Online enhancements: appendixes and supplemental tables.

\section{Introduction}

The configuration, sequence, and timing of collisions between various blocks that built Gondwana are a matter of ongoing research (e.g., Stern 1994; Meert 2003; Collins and Pisarevsky 2005). There is a general consensus that a north-south-striking system, the East African Orogen (EAO; Stern 1994), 2012.

Manuscript received September 30, 2011; accepted May 11,

* Author for correspondence; e-mail: kosuke.ueda@ platesinmotion.org. extends from the Arabian Shield in the north southerly into northern Mozambique. Collision along the northern part of the East African margin is reflected by metamorphic ages between ca. 640 and $550 \mathrm{Ma}$ (e.g., Coolen et al. 1982; Powell et al. 1993; Collins and Pisarevsky 2005; Cutten et al. 2006; Rossetti et al. 2008; Bingen et al. 2009). The southward continuation into Antarctica (East AfricanAntarctic Orogen [EAAO]: Jacobs et al. 1998, 2003; Jacobs 1999; Baba et al. 2010) is more controversial,

[The Journal of Geology, 2012, volume 120, p. 507-530] @ 2012 by The University of Chicago. All rights reserved. 0022-1376/2012/12005-0002\$15.00. DOI: 10.1086/666876 
and models with a younger, cross-cutting, eastwest-trending closure (i.e., the "Kuunga Orogen"; Meert 2003) have been proposed (fig. 1).

Younger, post-550 Ma metamorphic ages from the southern part of the EAAO (Mozambique and East Antarctica) are accompanied by large volumes of post-535 Ma granitoids and have been interpreted to reflect delamination of the lithosphere beneath the crustal segment south of the Lúrio Belt (Jacobs et al. 2008; Ueda et al. 2012). Lithospheric delamination can be expected to trigger crustal responses such as (1) rapid uplift due to basal unloading, (2) crustal extension, (3) increased heat flow, (4) high-temperature/low-pressure (HT-LP) metamorphism, (5) crustal partial melting, and (6) long-term slow cooling. In the southern part of the EAAO in northeast Mozambique, most of these criteria are met with evidence of late metamorphism, extensive partial melting and magmatism, and postcollisional deformation. In addition, a metamorphosed sequence of immature sediments has recently been reported that were deposited, deformed, and partially melted between ca. 530 and $500 \mathrm{Ma}$ (Thomas et al. 2010; Ueda et al. 2012). The subsequent thermal evolution of this part of the orogen has, however, not been fully documented, except for lower-temperature fission-track and limited ${ }^{40} \mathrm{Ar} /{ }^{39} \mathrm{Ar}$ studies (Daszinnies et al. 2009; Emmel et al. 2011).

In this study we present $43 \mathrm{U}-\mathrm{Pb}$ titanite, $144^{40} \mathrm{Ar} /$ ${ }^{39} \mathrm{Ar}$ hornblende, and $21{ }^{40} \mathrm{Ar} /{ }^{39} \mathrm{Ar}$ mica data from the major tectonic units in northeast Mozambique. In the light of potentially ambiguous time-temperature relationships, a large data set was employed to establish age ranges on a regional scale. These age ranges account for variability across samples of one block and are taken to describe the minimum age of high- to medium-grade metamorphism and the subsequent cooling of the various crustal domains robustly. We place particular emphasis on a comparison of the ages of the basement units north and south of the Lúrio Belt.

\section{Geological Background}

The high-grade basement of northeast Mozambique is made up of a collage of gneiss complexes with Meso- to Neoproterozoic protolith ages, which underwent amphibolite facies metamorphism during the late Ediacaran (Grantham et al. 2008; Bingen et al. 2009; Boyd et al. 2010; Macey et al. 2010). We refer to the (mostly orthogneissic) complexes north of the Lúrio Belt as the "northern basement," while

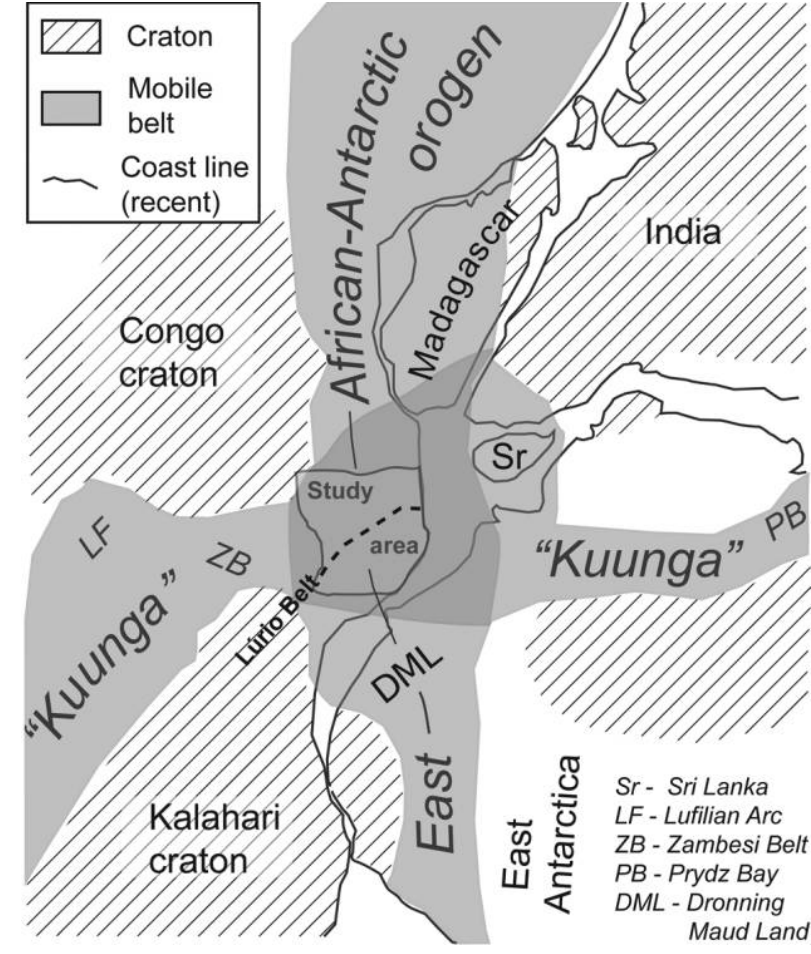

Figure 1. Reconstruction of Gondwana at ca. $550 \mathrm{Ma}$ and location of study area in northeast Mozambique, at the critical intersection of the East African-Antarctic and "Kuunga" Orogens. Modified from Bingen et al. (2009) following Meert (2003).

the single Nampula Complex to the south is accordingly termed "southern basement" (fig. 2).

The basement complexes are structurally overlain by a series of erosional remnants of granulitefacies high-strain nappes and klippen known as the Cabo Delgado Nappe Complex (CDNC) over the northern basement (Viola et al. 2008) and the Mugeba and Monapo klippen over the southern basement (Sacchi et al. 1984). Mesoproterozoic tectonic events are broadly termed $D_{1}\left(M_{1}\right)$, the main Ediacaran collision event (amalgamation of Gondwana) between ca. 600 and $550 \mathrm{Ma}$ is termed $\mathrm{D}_{2}$ $\left(M_{2}\right)$, and later events are termed $D_{3}\left(M_{3}\right)$. Each major event is locally further subdivided, for example $\mathrm{D}_{2 \mathrm{a}, \mathrm{b}}$ (cf. Ueda et al. 2012).

$\mathrm{U}-\mathrm{Pb}$ zircon and petrographic data from the northern basement record one phase of amphibolite facies metamorphism at ca. $550 \mathrm{Ma}$, while the northwesternmost terrane (Unango Complex) retains evidence of an older granulite-facies metamorphism at ca. $950 \mathrm{Ma}$ (Bingen et al. 2009; Boyd et al. 2010). In the Mesoproterozoic Nampula Complex, two potentially overlapping phases of meta- 


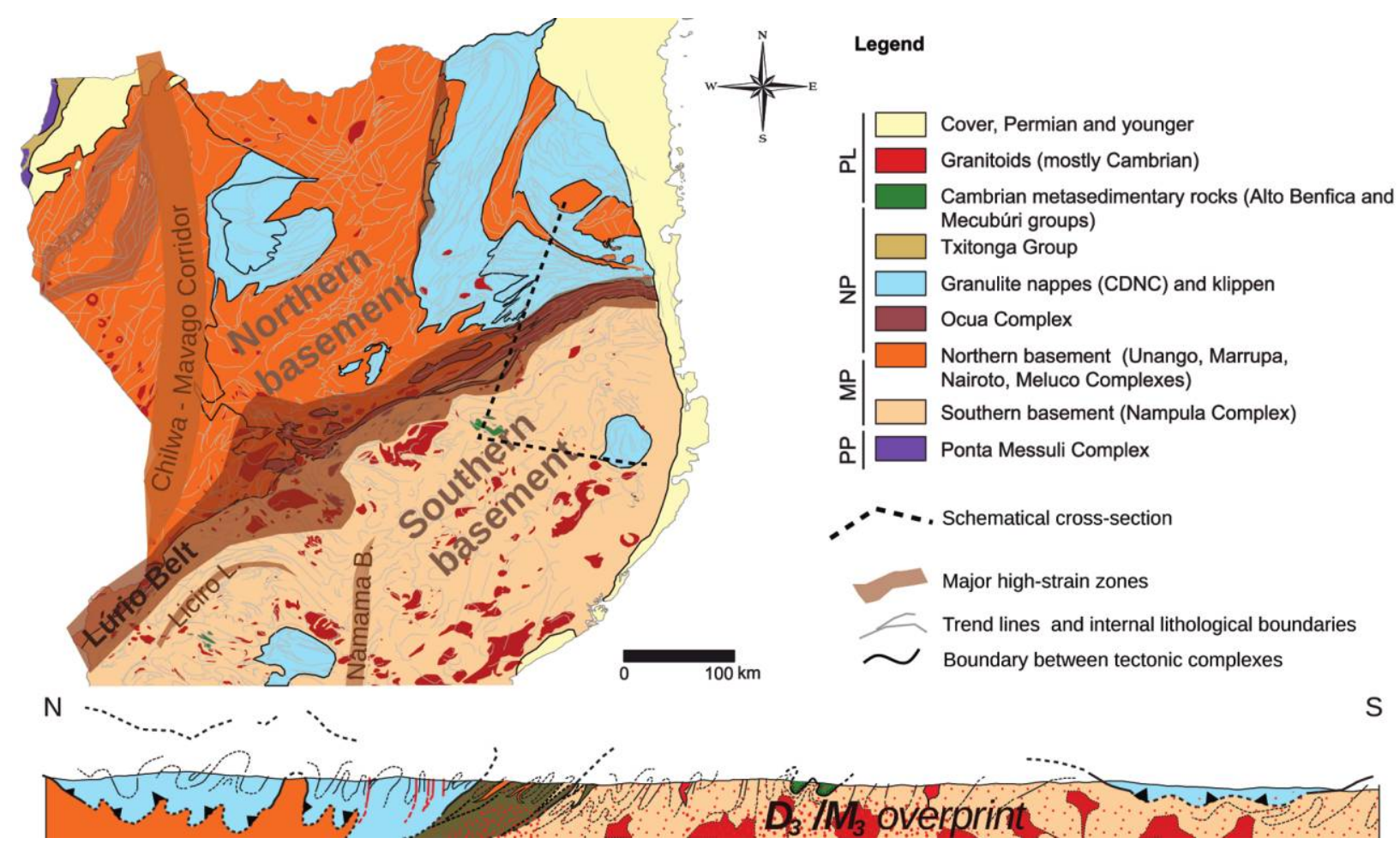

Figure 2. Simplified geological map of northeast Mozambique, showing main high-strain zones and a schematic north-south cross section with the main crustal elements. Note that the Mecuburi Group is folded into the Nampula Complex around northwest-southeast-oriented $\mathrm{D}_{3}$ fold axes, refolding older southeast-northwest $\mathrm{D}_{2}$ folds (the interference is only shown schematically). Protolith ages: PP, Paleoproterozoic; MP, Mesoproterozoic; NP, Neoproterozoic; PL, Paleozoic. Trend lines are from data from Norconsult Consortium (2007), satellite images, and aeromagnetics. Modified from Norconsult Consortium (2007), and Macey et al. (2010).

morphism occurred between ca. 550 and $490 \mathrm{Ma}$, under mid- to upper amphibolite facies conditions (Macey et al. 2007, 2010; Norconsult Consortium 2007; Grantham et al. 2008; Bingen et al. 2009).

The individual gneiss complexes of northeast Mozambique are separated and dissected by a number of high-strain shear zones (fig. 2). In the northwest, the northern basement is cut by a diffuse north-south-trending linear zone termed the "Chilwa-Mavago Corridor," which runs from the border with Tanzania to the Lúrio Belt and approximates the boundary between the Mesoproterozoic Unango and Marrupa Complexes. The ChilwaMavago Corridor has previously been interpreted as an array of Pan-African thrusts (Pinna et al. 1993). In the northwest of the Unango Complex, extensive arrays of anastomosing shear zones (e.g., the Macaloge Shear Zone; Bingen et al. 2009) connect with the Chilwa-Mavago Corridor and contain slivers of ca. 600 Ma metasedimentary rocks of marine affinity (Cobue and Geci Groups: Melezhik et al. 2006; Boyd et al. 2010). In the southwest, the southern basement is dissected by the Namama Belt (Cadoppi et al. 1987), a sinistral, steep, probably postcollisional shear zone (Macey et al. 2010).

The most important shear zone in the area is the east-northeast-trending, gently north-northwestdipping Lúrio Belt. This structure is a wide, complex, heterogeneous, and tectonically long-lived polyphase shear and boundary zone associated with granulite lenses (the Ocua Complex) that have largely mafic protoliths (Jourde and Vialette 1980; Viola et al. 2008; Boyd et al. 2010; Ueda et al. 2012). The kinematics are difficult to constrain due to protracted and polyphase deformation, but indications of late pure shear are prevalent (Viola et al. 2008). The spatial extent of the Lúrio Belt is also complex and can be defined in different but approximately spatially coincident ways (see Ueda et al. 2012), based on (a) discontinuous exposures of Ocua Complex rocks, $(b)$ the structural domains affected by intense aligned fabrics around the major lithological contacts, or $(c)$ a sharp linear magnetic anomaly in the east. The Lúrio Belt has been in- 
terpreted in a number of ways, including as $(a)$ a Mesoproterozoic or Ediacaran suture (Pinna et al. 1993; Grantham et al. 2008), (b) a transpressional, intraorogenic shear zone (Shackleton 1996), (c) a tectonic mélange (Viola et al. 2008), (d) a basal shear zone to the granulite-facies nappes (exposed to its north) that later became a focal zone of increasing fold strain (Viola et al. 2008), (e) an accommodation zone between two thermomechanically different parts of the orogen (Jacobs et al. 2008), or more generally $(f)$ as crustal-scale discontinuity of unknown origin that was repeatedly reactivated and reworked with varying kinematics over a wide area (Ueda et al. 2012). In the eastern Lúrio Belt, peak metamorphic conditions and pressure-temperature-time evolution indicate an almost isothermal decompression path from ca. $950^{\circ} \mathrm{C}$ and $1.57 \mathrm{GPa}$ to a lower-pressure granulite-facies stage, cooling into amphibolite facies after $557 \mathrm{Ma}$ (Engvik et al. 2007). The central Lúrio Belt shows evidence for later tectonic activity accompanying a second phase of HP/LT metamorphism and the emplacement of granitoids around $515 \mathrm{Ma}$ (Ueda et al. 2012). Waning of the first, collision-related phase of high-grade metamorphism is marked by incipient extension at ca. 540-530 Ma (Viola et al. 2008). This date is interpreted to represent the timing of the general onset of extension in northeast Mozambique. In this study we define the Lúrio Belt as the envelope of all Ocua Complex outcrops, connected along structural trend lines, and the structurally coincident domains within the adjacent basement blocks, including slivers of intersliced high-strain basement lithologies (fig. 2; cf. Ueda et al. 2012).

A system of thrust slices known as the Cabo Delgado Nappe Complex (CDNC: Viola et al. 2008), is composed of Neoproterozoic granulite facies rocks that tectonically overlie ca. $20 \%$ of the area north of the Lúrio Belt (fig. 2). The main eastern exposure of these rocks consists of predominantly supracrustal nappes with protolith ages of ca. 820-700 $\mathrm{Ma}$, intercalated with ca. 1050-950-Ma basement orthogneisses, equivalent to the Marrupa and Unango Complexes to the northwest (Bingen et al. 2009; Boyd et al. 2010). No quantitative pressuretemperature $(P T)$ or metamorphic age data are available from the CDNC, but in general the rocks are characterized by amphibolite-facies metamorphism and also contain lenses of granulite-facies rocks (Boyd et al. 2010).

Further west, a large klippe contains two complexes with nappe-like character (the $\mathrm{M}^{\prime}$ Sawize and Muaquia Complexes; Boyd et al. 2010) that abut the contact between the Marrupa and Unango Complexes. In the M'Sawize Complex, early HP granulite-facies metamorphism was followed by conditions of ca. $800^{\circ} \mathrm{C}$ and $1.15 \mathrm{GPa}$ (Boyd et al. 2010).

South of the Lúrio Belt, two discordant Neoproterozoic granulite-facies units, the Monapo and Mugeba klippen, overlie the Nampula Complex and possibly represent remnants of southern equivalents of the CDNC (e.g., Viola et al. 2008). U-Pb zircon ages of ca. 615-580 Ma are reported for samples from these southern klippen, and PT estimates follow a path of isothermal decompression, from peak conditions of ca. $900^{\circ}-1000^{\circ} \mathrm{C}$ and $>1 \mathrm{GPa}$ at ca. $615 \mathrm{Ma}$ to upper amphibolite facies $\left(\sim 700^{\circ} \mathrm{C}\right.$, $<0.7 \mathrm{GPa}$ ) at around 590-570 Ma (Kröner et al. 1997; Grantham et al 2008).

Large volumes of granitoids were emplaced between ca. 530 and $490 \mathrm{Ma}$ into the Lúrio Belt and the southern basement (fig. 2; Jacobs et al. 2008; Bingen et al. 2009; Macey et al. 2010). This magmatism, largely absent from the northern basement, is likely related to extensive migmatization (fig. 3a) in domains that were tectonically reworked during the Cambrian (Thomas et al. 2010; Ueda et al. 2012).

The southern basement (Nampula Complex) is unconformably overlain by two sequences of Cambrian metasedimentary rocks, the Alto Benfica and Mecubúri groups (fig. 2). These immature clastic sediments were sourced regionally from the basement on either side of the Lúrio Belt and the CDNC and thus reflect erosion and deposition after juxtaposition of these units during the main Neoproterozoic collision of the EAAO (Thomas et al. 2010). These sequences occur within a zone of late northwest-trending structures that variably overprinted earlier, collision-related northeast-trending fabrics across the Nampula Complex. The late structural history $\left(D_{3}\right)$ has been interpreted to reflect transtensional folding following delamination of the orogenic root under the Nampula Complex and associated extensional collapse (Ueda et al. 2012). HT-LP metamorphism and migmatization characterize a widespread late metamorphism south of the Lúrio Belt, in which peak conditions of $>675^{\circ} \mathrm{C}$ and $>0.25 \mathrm{GPa}$ were reached around 520 $515 \mathrm{Ma}$ and temperatures of $>600^{\circ} \mathrm{C}$ were maintained at least until ca. $470 \mathrm{Ma}$ (Ueda et al. 2012). The main features of the crust in northeast Mozambique are shown in a schematic cross section (fig. 2).

\section{Samples and Analytical Methods}

$\mathrm{U}-\mathrm{Pb}$ (titanite) and ${ }^{40} \mathrm{Ar} /{ }^{39} \mathrm{Ar}$ (hornblende, biotite, phlogopite, and white mica) analyses were per- 

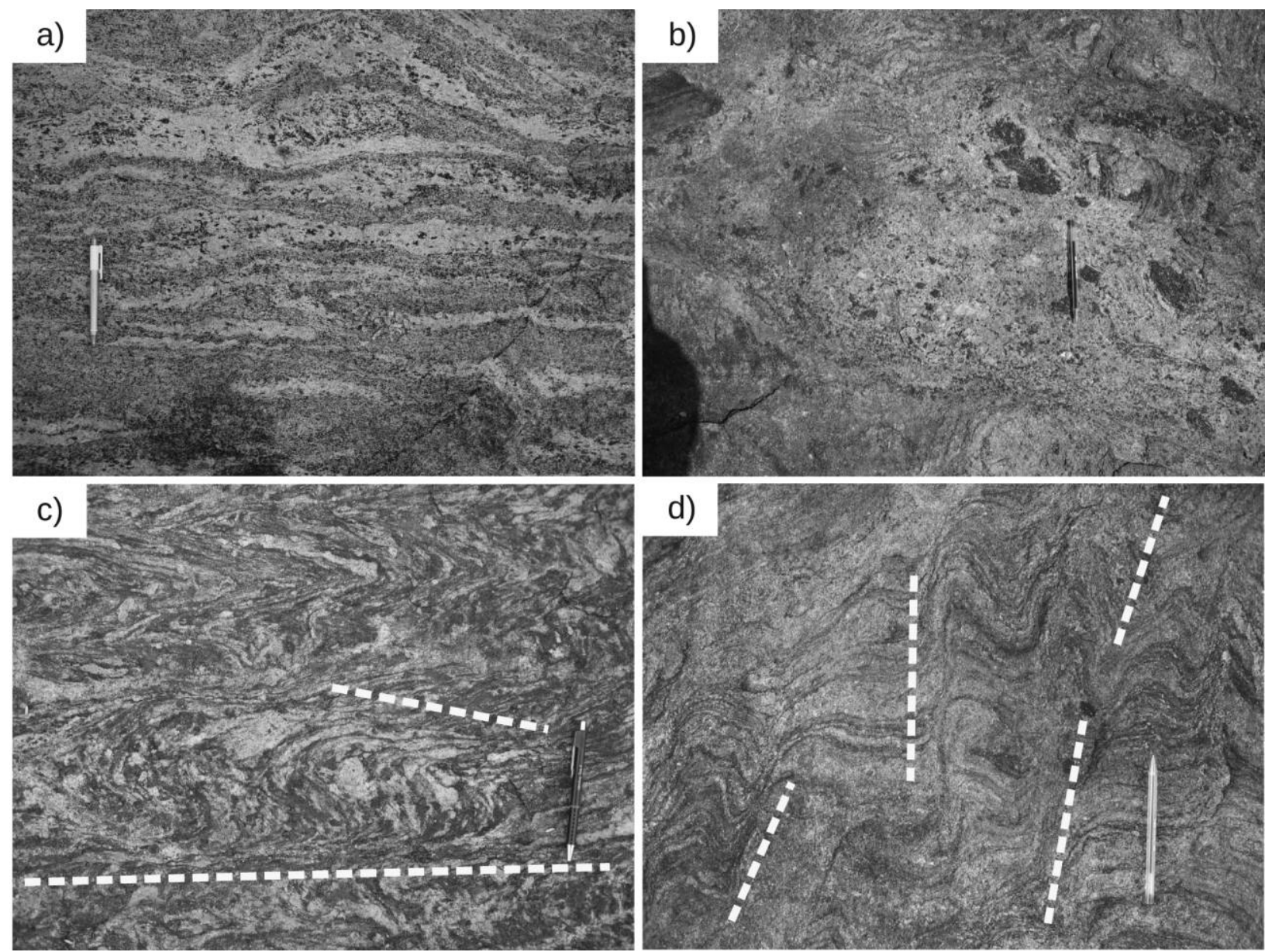

Figure 3. Evidence of diatexis in the western Nampula Complex. $a$, Stromatic migmatite; $b$, typical nebulous migmatite with advanced diatexis; and $c, d$, mesoscale crenulation cleavage (probably extensional) associated with leucosomes along $\mathrm{C}^{\prime}$ planes and offsetting migmatitic banding (S planes). White hatched lines have been drawn parallel (but offset for clarity) to the $\mathrm{C}^{\prime}$ planes, which vary slightly in orientation.

formed on samples from various representative lithologies that were collected during a World Bank and Nordic Development Fund-funded mapping project and that are stored by the Mozambican Geological Survey (Direcção Nacional de Geologia). These were complemented by samples collected during a later field campaign to improve regional sample coverage. Samples were selected for analyses after separate petrographic and mineral inspection. Samples with optically fresh grains of hornblende and micas were preferred to separates with inclusions, fractures, and cloudiness when viewed under a binocular microscope. Titanite grains were extracted from fresh samples either (1) separated using a Wilfly table and magnetic and heavy liquid separation or (2) by handpicking grains from crushed whole-rock samples. Separates for ${ }^{40} \mathrm{Ar} /{ }^{39} \mathrm{Ar}$ analyses were all obtained by method (2). In order to make a thermal regional interpretation, we assumed that the ages are generally cooling ages and that potential exceptions would lead to similar scatter in all the units that can be regarded as an additional external uncertainty. We use initial estimates of geologically reasonable U-Pb and Ar closure temperatures (following those given by Willigers et al. 2001 for a standard grain size and cooling rate) of $\geq 660^{\circ} \mathrm{C}$ for the U-Pb titanite system (Scott and St.-Onge 1995), ca. $500^{\circ} \mathrm{C}$ for the ${ }^{40} \mathrm{Ar} /$ ${ }^{39} \mathrm{Ar}$ hornblende system (Harrison 1981), ca. $410^{\circ} \mathrm{C}$ for the ${ }^{40} \mathrm{Ar} /{ }^{39} \mathrm{Ar}$ muscovite system (Hames and Bowring 1994), and ca. $310^{\circ} \mathrm{C}$ for the ${ }^{40} \mathrm{Ar} /{ }^{39} \mathrm{Ar}$ biotite system (Grove and Harrison 1996). Closure temperatures were iteratively recalculated from measured grain sizes and cooling rates inferred from our new dating results, and are reported below.

U-Pb Titanite Analyses. Analyses were performed using multiple-collector laser ablation inductively 


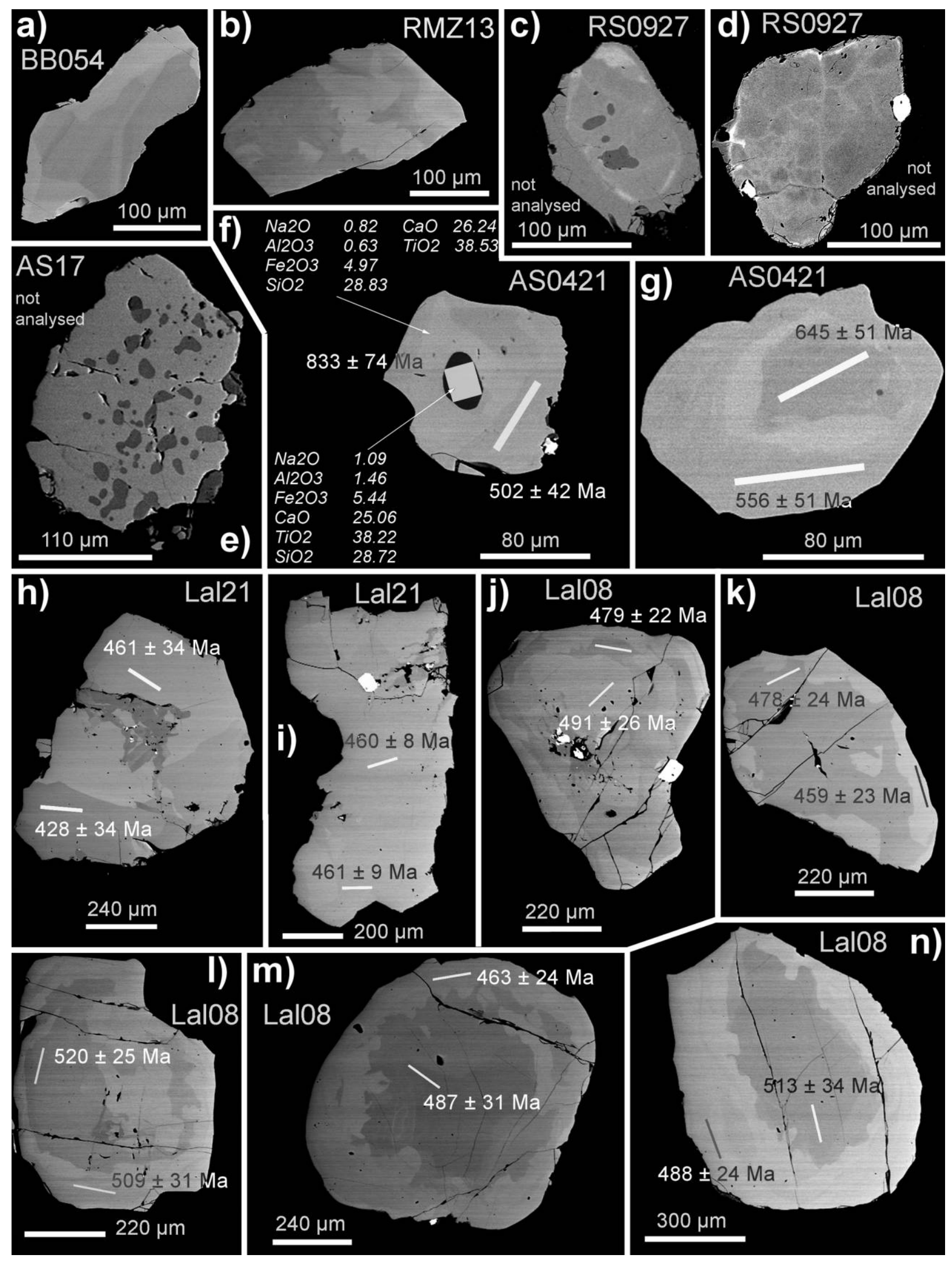


coupled plasma mass spectrometers (LA-ICPMS) at the University of Bergen and the NERC Isotope Geosciences Laboratory (NIGL), Keyworth, United Kingdom. Depending on the population in the sample, 30 to 60 grains per sample of $75-300-\mu \mathrm{m}$ diameter grains were handpicked under a binocular microscope and embedded in a 2.5-cm-diameter epoxy mount. In two samples (Lal08, Lal21), grains up to $500 \mu \mathrm{m}$ in size were also analyzed. Mounts were polished to expose the grains, which were imaged by backscattered electron (BSE) microscopy in order to document chemical zoning (fig. 4). Details of the analytical protocols for both laboratories are listed in appendix A, available in the online edition or from the Journal of Geology office.

Where possible, the analyses were corrected individually for common lead, and concordia ages were calculated with ISOPLOT (Ludwig 2008). For other samples, common lead determinations were unreliable due to low ${ }^{204} \mathrm{~Pb}$ content. In these cases, regressions through uncorrected measurements were used in Tera-Wasserburg plots and anchored through a ${ }^{207} \mathrm{~Pb} /{ }^{206} \mathrm{~Pb}$ intercept of $0.83 \pm 0.02$ (i.e., present-day average terrestrial lead composition; Stacey and Kramers 1975). The plots are shown in figures 5 and 6; a summary of the ages is given in table 1 ; a detailed description of the analyses and the samples is given in appendix B, "Rock Description, Mineral Characterization, and Analytical Results," available in the online edition or from the Journal of Geology office; and a complete table of all data is provided in supplementary table $\mathrm{S1}$, also available online or from the Journal of Geology. All quoted ages have uncertainties of $2 \sigma$.

${ }^{40} \mathrm{Ar} /{ }^{39} \mathrm{Ar}$ Hornblende and Mica Analyses. The ${ }^{40} \mathrm{Ar} /$ ${ }^{39} \mathrm{Ar}$ analyses were performed at the Western Australian Argon Isotope Facility at Curtin University and at the Noble Gas Laboratory at Rutgers University (RT) with age standards being analyzed at the Noble Gas Geochemistry and Geochronology
Laboratories at Arizona State University. We separated unaltered, optically clear, ca. $150-\mu \mathrm{m}$-size hornblende, biotite, phlogopite, and muscovite grains, specifically checking for the occurrence and intergrowth of other K-bearing mineral phases. An aliquot of hornblende from the selected grains of each sample was additionally examined for internal structures, homogeneity, and potential intergrowth of other mineral phases using BSE imaging. Further details of the analytical procedures can be found in appendix A. The integrated ages $(2 \sigma)$, plateau ages $(2 \sigma)$, and inverse isochron ages $(2 \sigma$ or $95 \%$ confidence) are reported in table 2 and figures 7 and 8 , and detailed isotopic data are provided in supplementary tables S2 and S3, available in the online edition or from the Journal of Geology office.

\section{Results}

U-Pb results of 43 titanite samples, and ${ }^{40} \mathrm{Ar} /{ }^{39} \mathrm{Ar}$ results of 14 hornblende, 1 phlogopite, 2 muscovite, and 18 biotite samples are reported in tables 1 and 2 and figures 5-8; the results are detailed together with sample descriptions in appendix B. For comparative purposes all the results for the ${ }^{40} \mathrm{Ar} /{ }^{39} \mathrm{Ar}$ and $\mathrm{U}-\mathrm{Pb}$ titanite systems from this and relevant previous studies are shown on figure 9. In the following section, the dating results are presented in a shortened form by each geochronological system.

U-Pb Titanite Data. Most titanite grains showed no chemical zoning in the BSE images. The origin of the diverse chemical zoning observed in some grains (fig. 4) is unclear, and an interpretation with geological implications is ambiguous. Semiquantitative electron-microbeam analyses using the $\mathrm{x}$ ray energy-dispersive spectroscopy detector of the SEM could not detect any significant compositional differences (e.g., fig. 4f). The ages of the outer (rim) and inner (core) concentric zones in individual grains overlap within error (fig. $4 j-4 n$ ). The chem-

Figure 4. Backscattered electron images of selected titanite grains. $a$, Straight zone boundaries (oscillatory or sector zoning) and possible concentric overgrowth. $b$, Nebulous, schlieren-like zoning. $c$, Apparent resorption of former grain and overgrowth. $d$, Apparent fracturing and healing. e, "Leopard-pattern" titanite-in-titanite texture. The darker titanite phase is relatively rich in Fe and $\mathrm{Al}$ (semiquantitative energy-dispersive spectroscopy [EDS] data), possibly reflecting a higher-pressure composition (see Frost et al. 2001). $f$, Two-phase titanite with different imprecise individual ages in sample AS0421 from the Cabo Delgado Nappe Complex (CDNC; figs. 2, 5). The central phase is more Al rich, and its age corresponds to crystallization ages obtained for the CDNC (Boyd et al. 2010), while the external phase yields an age similar to the postcollisional metamorphism seen elsewhere in the CDNC. Compositional data (compound weight\%) obtained with EDS (x-ray) and semiquantitative (relative analytical uncertainties are ca. 15\%). $g$, Diffuse zoning in the outer part of a titanite grain from the same sample. $h, i$, Two large grains from sample Lal2 1 showing different ages controlled by zoning (composition) but not by position within grain. $j-n$, Large grains from sample Lal08. Lines on grains show location of ablation track. Rim analyses are younger than core analyses for any one grain, but overlap within the sample. All ages are ${ }^{206} \mathrm{~Pb} /{ }^{238} \mathrm{U}$ ages after common lead correction. 

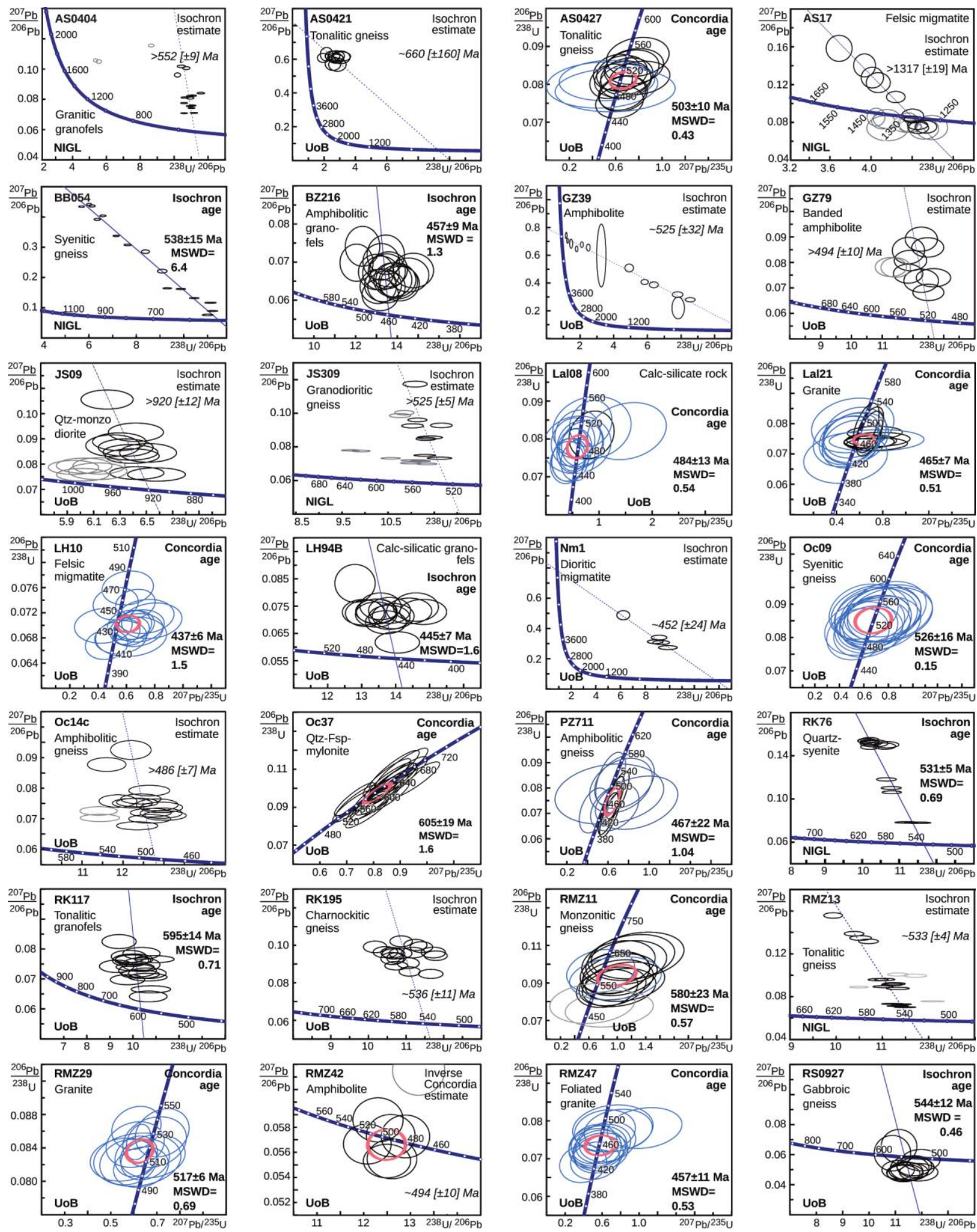

Figure 5. Results of U-Pb titanite analyses from the northern basement, Cabo Delgado Nappe Complex, granulite klippen, and the Lúrio Belt. Conventional concordia diagrams show data corrected for common Pb (blue ellipses, with black ellipses showing uncorrected data). Anchored regressions through common Pb-uncorrected analyses are shown in Tera-Wasserburg diagrams (MSWD not shown when spread is low). Gray ellipses denote analyses that have been excluded when obtaining estimates. Individual analyses shown at $1 \sigma$ level of uncertainty; the concordia age ellipses (red) at $2 \sigma$. 

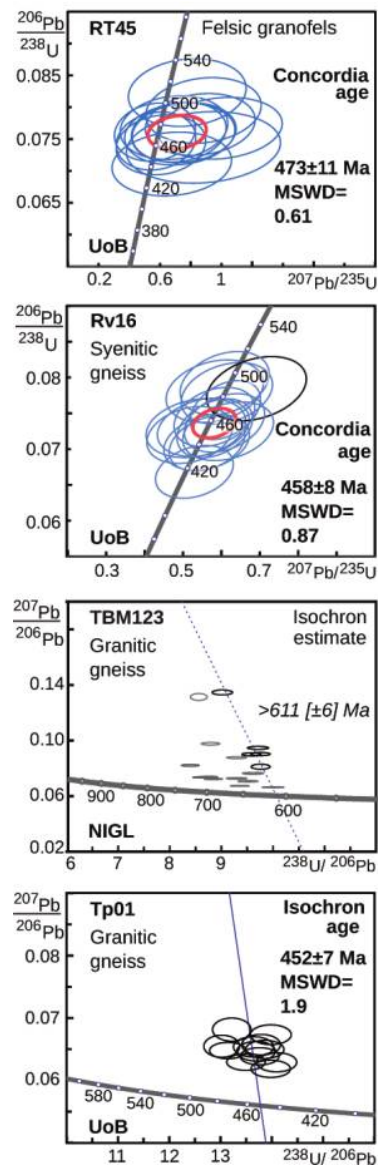
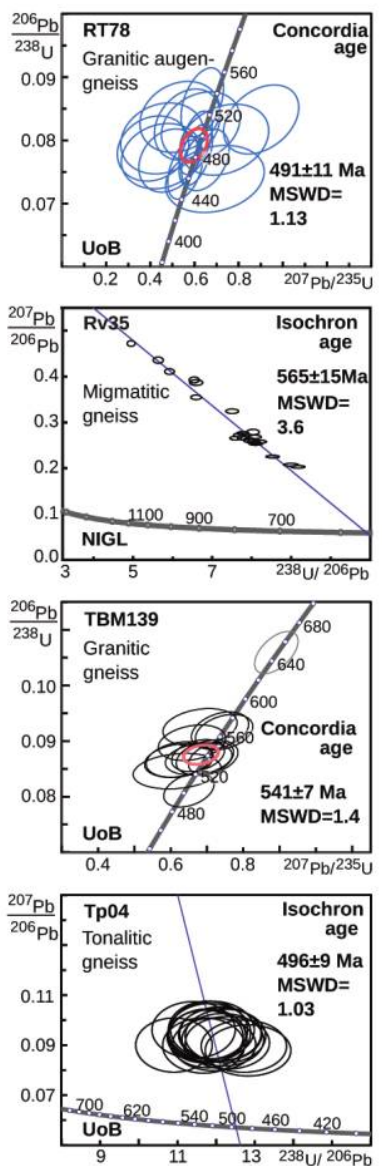
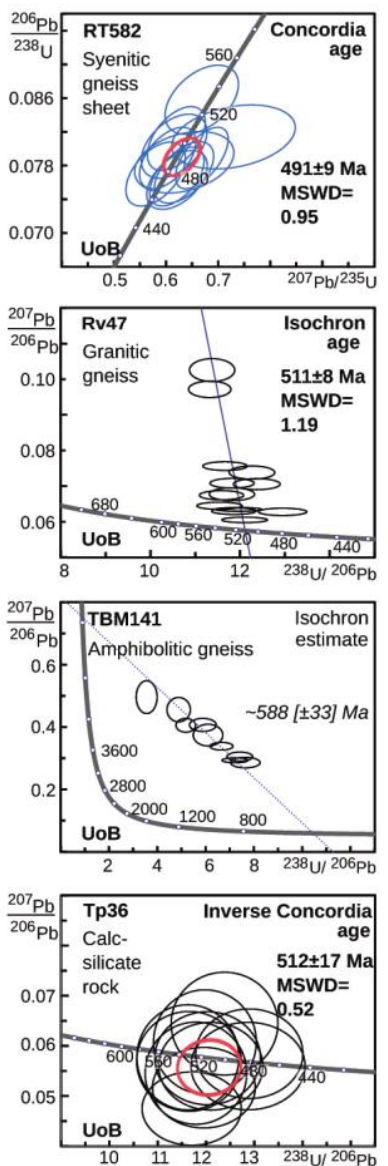
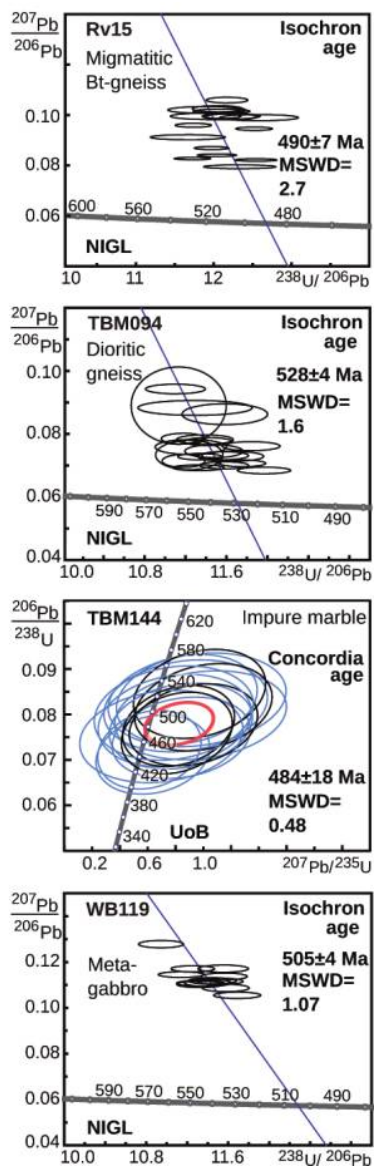

Figure 6. Results of U-Pb titanite analyses from the Lúrio Belt and the Nampula Complex (southern basement). Legend and statistics as for fig. 5.

ical zoning could reflect either new growth or local differences in rare earth elements and $\mathrm{Fe},(\mathrm{Al}$ and $\mathrm{Ca})$ contents, possibly including $\mathrm{Pb}$ (e.g., Aleinikoff et al. 2002; Willigers et al. 2002; Jung and Hellebrand 2007; Storey et al. 2007). Alternatively, the compositional variations could be caused by a dynamic equilibrium between titanite and the surrounding material (without new growth needed) in reaction to changing pressures, temperatures, and/ or the composition of metamorphic fluids (Frost et al. 2001). Like polyphase growth (during major crystallization events), these may produce complex results (in this case late with regard to main crystallization) and nonanalytical scatter of analyses. For example, Willigers et al. (2001) suggested heterogeneous closure temperatures in titanite fragments from the same sample, caused by varying diffusion radii (cracks, crystal defects) as a potential source of natural age scatter and complexity. Therefore, both the central (median or mean) ages and complex age distributions should be interpreted with this caveat in mind when correlating data with either single or multiple tectonic events.

Although generally only simple titanite samples were selected, which did not exhibit optical indications of polyphase growth, some samples still yielded relatively complex results. For these samples, data points showed nonanalytical scatter that may reflect tectonic or $\mathrm{Pb}$ diffusion complexity. The scatter led to a poor fit of simple age models or required the selection of an arbitrary subset in order to obtain a quantitative result. In the case that selective pooling excluded analytically flawless data, and especially where several ways of grouping were possible, these ages can only be considered as estimates (figs. 5, 6; table 1). We distinguish in the following section between robust ages, termed "dates," that describe all analytically valid analyses of a sample, where data concordance was verified using reduced $\chi^{2}$ statistical tests (i.e., MSWD values), and age "estimates" that fail such criteria or are obtained by selection of data. U-Pb 
Table 1. Summary of U-Pb Titanite Analyses

\begin{tabular}{|c|c|c|c|c|c|c|c|c|c|}
\hline \multirow[b]{2}{*}{ Sample } & \multirow[b]{2}{*}{ Lithology } & \multirow[b]{2}{*}{$\begin{array}{l}\text { Tectonic unit } \\
\text { (complex) }\end{array}$} & \multicolumn{4}{|c|}{ Date } & \multicolumn{3}{|c|}{ Estimate } \\
\hline & & & $\begin{array}{l}\text { Age } \\
\text { (Ma) }\end{array}$ & $\begin{array}{l} \pm 2 \sigma \\
(\mathrm{Ma})\end{array}$ & MSWD & $P(n)$ & $\begin{array}{l}\text { Age } \\
\text { (Ma) }\end{array}$ & $\begin{array}{l} \pm 2 \sigma^{\mathrm{a}} \\
(\mathrm{Ma})\end{array}$ & $(n)$ \\
\hline AS0421 & Tonalitic gneiss & CDNC (Xixiano) & & & & & $\sim 660$ & 160 & (11) \\
\hline $\mathrm{Oc} 14 \mathrm{c}$ & Amphibolitic gneiss & CDNC (Montepuez) & & & & & $>486$ & 7 & (12) \\
\hline Rv16 & Syenitic gneiss & CDNC (Lalamo) & 458 & 8 & .87 & $.67(16)$ & & & \\
\hline Rv35 & Migmatitic gneiss & CDNC (Montepuez) & 565 & 15 & 3.60 & $.00(20)$ & & & \\
\hline TBM123 & Granitic gneiss & CDNC (Lalamo) & & & & & $>611$ & 6 & $(6)$ \\
\hline TBM141 & Amphibolitic gneiss & CDNC (Lalamo) & & & & & $\sim 588$ & 33 & (6) \\
\hline TBM144 & Impure marble & CDNC (Montepuez) & 484 & 18 & .48 & $.99(16)$ & & & \\
\hline RK117 & Tonalitic granofels & NK (M'Sawize) & 595 & 14 & .71 & $.78(17)$ & & & \\
\hline RMZ11 & Monzonitic gneiss & SK (Monapo) & 580 & 23 & .57 & $.96(14)$ & & & \\
\hline $\mathrm{RMZ}^{1} 1^{\mathrm{b}}$ & $\sim$ & $\sim$ & & & & & $\sim 478$ & 44 & (2) \\
\hline BB054 & Syenitic gneiss & LB (Ocua) & 538 & 15 & 6.40 & $.00(16)$ & & & \\
\hline Lal08 & Calc-silicate rock & LB (Ocua) & 484 & 13 & .54 & $.98(15)$ & & & \\
\hline Lal21 & Alkali-feldspar granite & LB (Malema suite) & 465 & 7 & .51 & $.99(17)$ & & & \\
\hline LH94B & Calc-silicatic granofels & LB (Unango) & 445 & 7 & 1.60 & $.02(15)$ & & & \\
\hline Oc09 & Syenitic gneiss & LB (Ocua) & 526 & 16 & .15 & $1.00(16)$ & & & \\
\hline OC37 & $\begin{array}{l}\text { Quartz-feldspar } \\
\text { mylonite }\end{array}$ & LB (Ocua) & 605 & 19 & 1.60 & $.012(19)$ & & & \\
\hline RMZ42 & Amphibolite & LB (Nampula) & & & & & $\sim 494$ & 10 & (6) \\
\hline RT45 & Felsic granofels & LB (Ocua) & 473 & 11 & .61 & $.94(13)$ & & & \\
\hline RT582 & Syenitic gneiss sheet & LB (Ocua) & 491 & 9 & .95 & $.52(13)$ & & & \\
\hline RT78 & Granitic augen-gneiss & LB (Unango) & 491 & 11 & 1.13 & $.28(15)$ & & & \\
\hline TBM094 & Dioritic gneiss & LB (Ocua) & 528 & 4 & 1.60 & $.06(18)$ & & & \\
\hline $\mathrm{Tp} 04$ & Tonalitic gneiss & LB (Ocua) & 496 & 9 & 1.03 & $.42(17)$ & & & \\
\hline Tp36 & Calc-silicate rock & LB (Ocua) & 512 & 17 & .52 & $.96(11)$ & & & \\
\hline WB119 & Meta-gabbro & LB (Nampula) & 505 & 4 & 1.07 & $.39(12)$ & & & \\
\hline AS0404 & Granitic granofels & NB (Marrupa) & & & & & $>552$ & 9 & $(15)$ \\
\hline AS17 & Felsic migmatite & NB (Unango) & & & & & $>1317$ & 19 & (9) \\
\hline JS09 & Quartz-monzodiorite & NB (Unango) & & & & & $>920$ & 12 & (9) \\
\hline JS309 & Granodioritic gneiss & NB (Meluco) & & & & & $>525$ & 5 & (7) \\
\hline RK195 & Charnockitic gneiss & NB (Unango) & & & & & $\sim 536$ & 11 & (17) \\
\hline RK76 & Quartz syenite & NB (Unango) & 531 & 5 & .69 & $.79(15)$ & & & \\
\hline RS0927 & Gabbroic gneiss & NB (Marrupa) & 544 & 12 & .46 & $.93(9)$ & & & \\
\hline Rv15 & $\begin{array}{l}\text { Migmatitic biotite- } \\
\text { gneiss }\end{array}$ & NB (Meluco) & 490 & 7 & 2.70 & $.00(16)$ & & & \\
\hline TBM139 & Granitic gneiss & NB (Meluco) & 541 & 7 & 1.40 & $.08(12)$ & & & \\
\hline AS0427 & Tonalitic gneiss & SB (Nampula) & 503 & 10 & .43 & $.51(16)$ & & & \\
\hline $\mathrm{BZ} 216$ & Amphibolitic granofels & SB (Nampula) & 457 & 9 & 1.30 & $.2(18)$ & & & \\
\hline GZ39 & Amphibolite & SB (Nampula) & & & & & $\sim 525$ & 32 & $(12)$ \\
\hline GZ79 & Banded amphibolite & SB (Nampula) & & & & & $>494$ & 10 & $(8)$ \\
\hline LH10 & Felsic migmatite & SB (Nampula) & 437 & 6 & 1.50 & $.06(13)$ & & & \\
\hline $\operatorname{Mec} 11^{\mathrm{c}}$ & Mafic dyke & SB (Mecuburi Grp.) & 471 & 9 & .70 & $.88(14)$ & & & \\
\hline $\mathrm{Nm} 1$ & Migmatitic diorite & SB (Nampula) & & & & & $\sim 452$ & 24 & $(5)$ \\
\hline PZ711 & Amphibolitic gneiss & SB (Nampula) & 467 & 22 & 1.04 & $.41(12)$ & & & \\
\hline RMZ13 & Tonalitic gneiss & SB (Nampula) & & & & & $\sim 533$ & 4 & (14) \\
\hline RMZ29 & Granite & SB (Nampula) & 517 & 6 & .69 & $.86(16)$ & & & \\
\hline RMZ47 & Foliated granite & SB (Nampula) & 457 & 11 & .53 & $.98(14)$ & & & \\
\hline Rv47 & Granitic gneiss & SB (Nampula) & 511 & 8 & 1.19 & $.29(13)$ & & & \\
\hline Tp01 & Granitic gneiss & SB (Nampula) & 452 & 7 & 1.90 & $.03(12)$ & & & \\
\hline
\end{tabular}

Note. Dates refer to reliable ages either from concordia calculation or Tera-Wasserburg regressions (see figs. 6, 7; tables S1, S2, and S3, available online or from the Journal of Geology). Age estimates list approximate results that are of low precision or where the fit of a single age is not justified due to nonanalytical scatter. $P(n)$, probability of fit (no. analysis). $\mathrm{CDNC}=$ Cabo Delgado Nappe Complex, NK = Northern klippen, SK = Southern klippen, LB = Lúrio Belt, NB = Northern basement, $\mathrm{SB}=$ Southern basement, and Grp. = Group.

a Nominal error of estimate calculation.

b Two younger analyses.

c Ueda et al. 2012. 


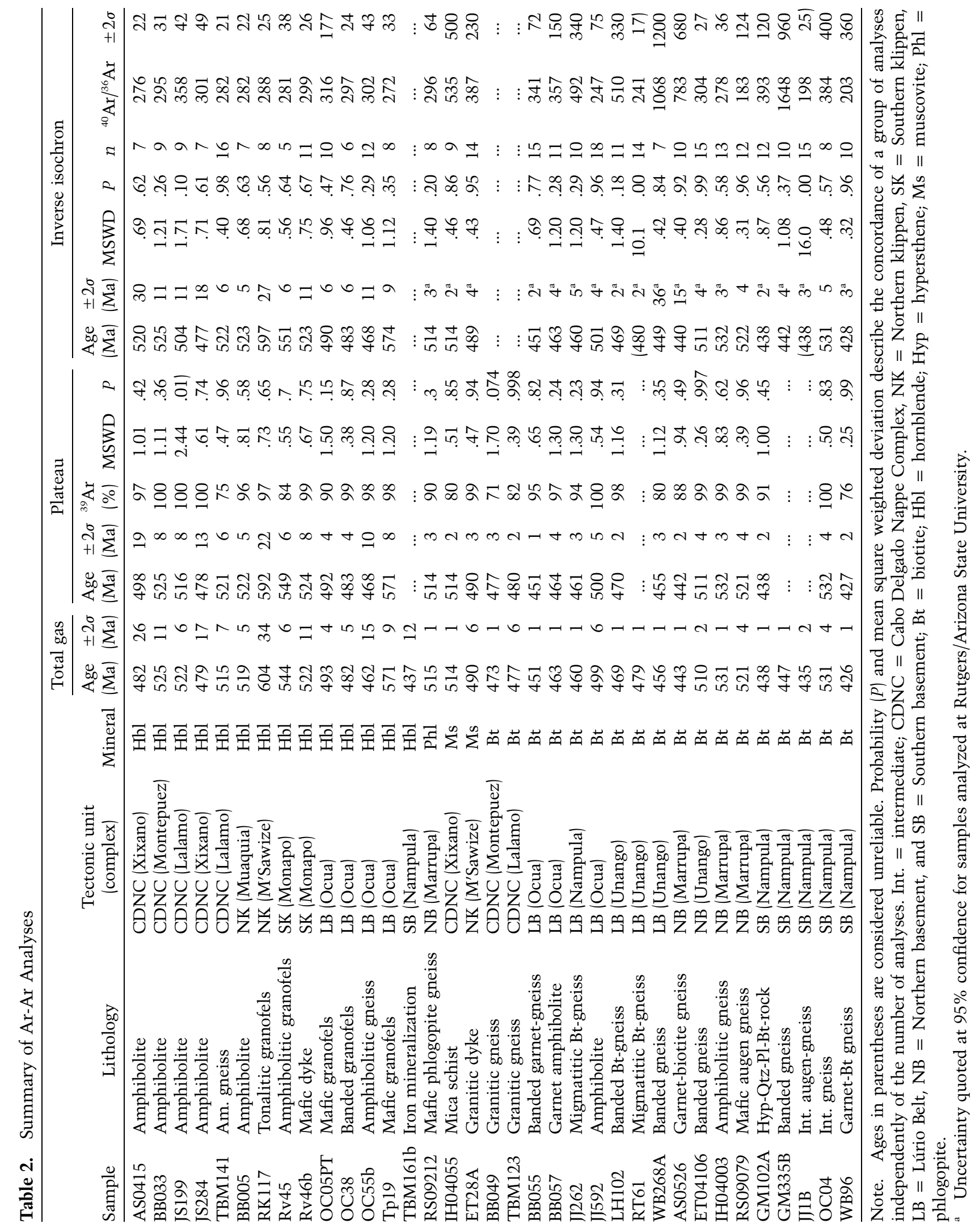



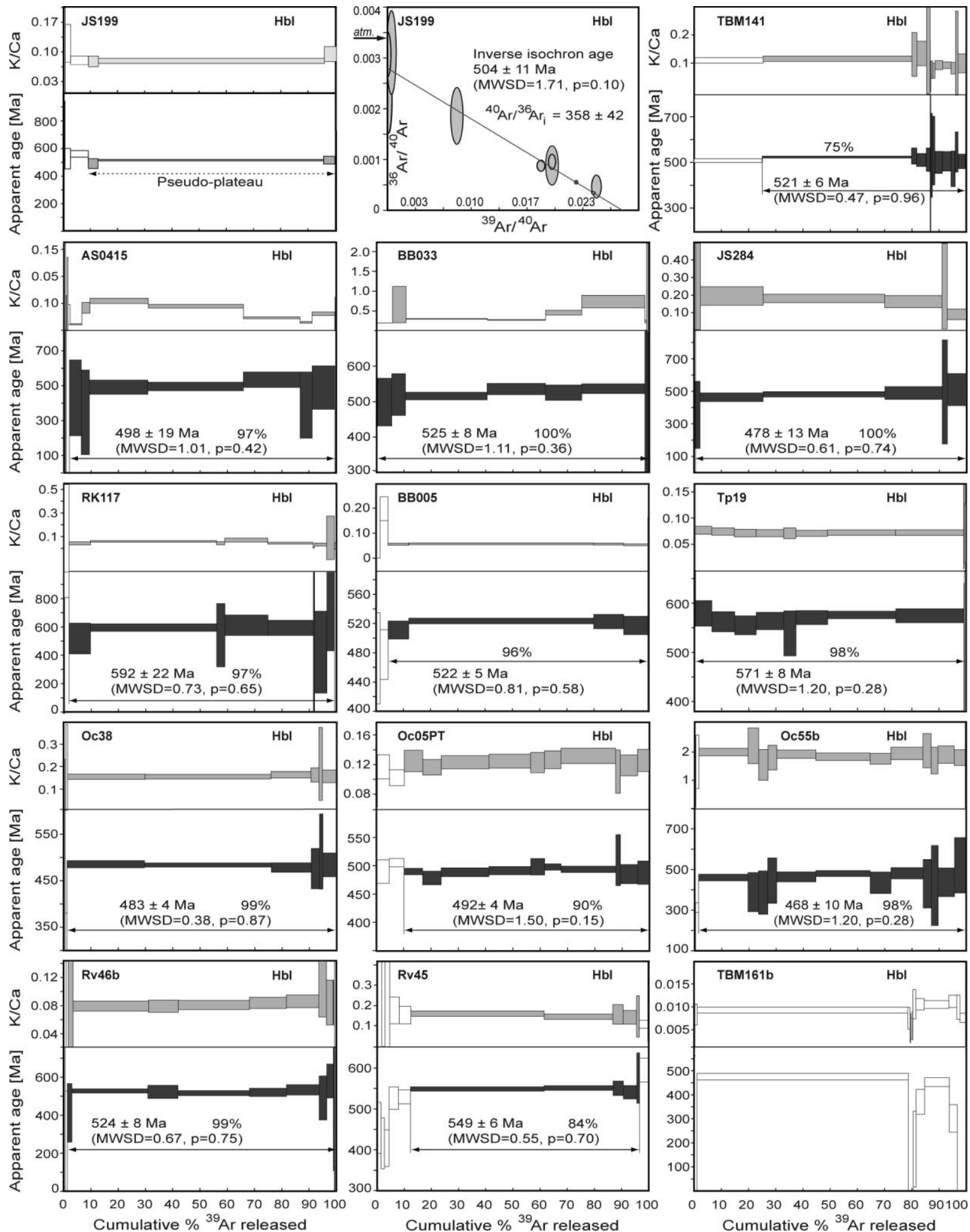

Figure 7. Results of ${ }^{40} \mathrm{Ar} /{ }^{39} \mathrm{Ar}$ hornblende analyses. $\mathrm{K} / \mathrm{Ca}$ and ${ }^{40} \mathrm{Ar} /{ }^{39} \mathrm{Ar}$ apparent age spectrum plots for most hornblende samples and inverse isochron plot for sample JS199. The plateau ages are given at the $2 \sigma$ level of significance. All samples analyzed at the Western Australian Argon Isotope Facility. 

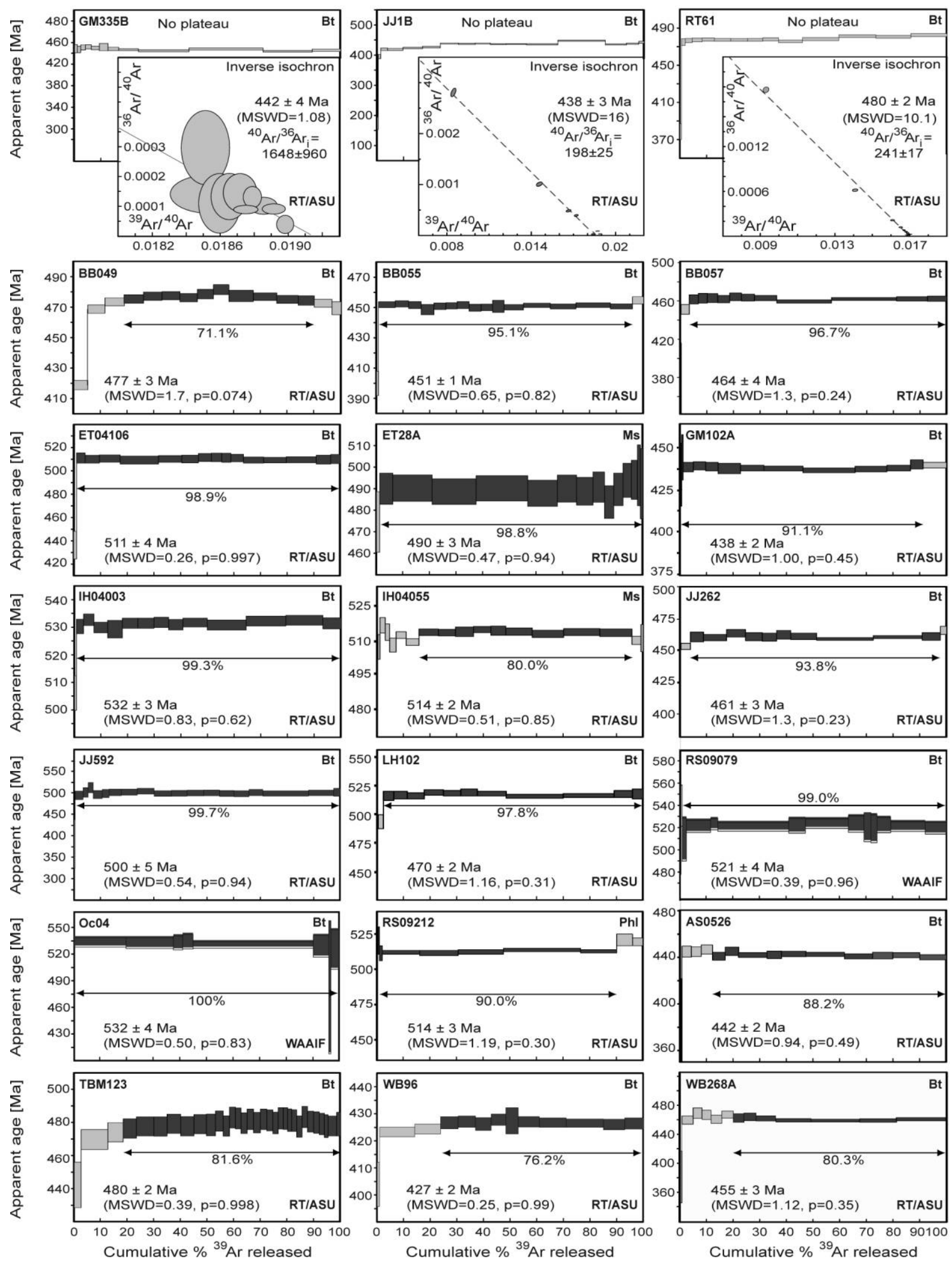

Figure 8. Results of ${ }^{40} \mathrm{Ar} /{ }^{39} \mathrm{Ar}$ biotite, phlogopite and muscovite analyses, with ${ }^{40} \mathrm{Ar} /{ }^{39} \mathrm{Ar}$ apparent age spectra for three samples that yielded no plateau. The plateau ages have $2 \sigma$ errors. The inverse isochron ages have $95 \%$ confidence. 


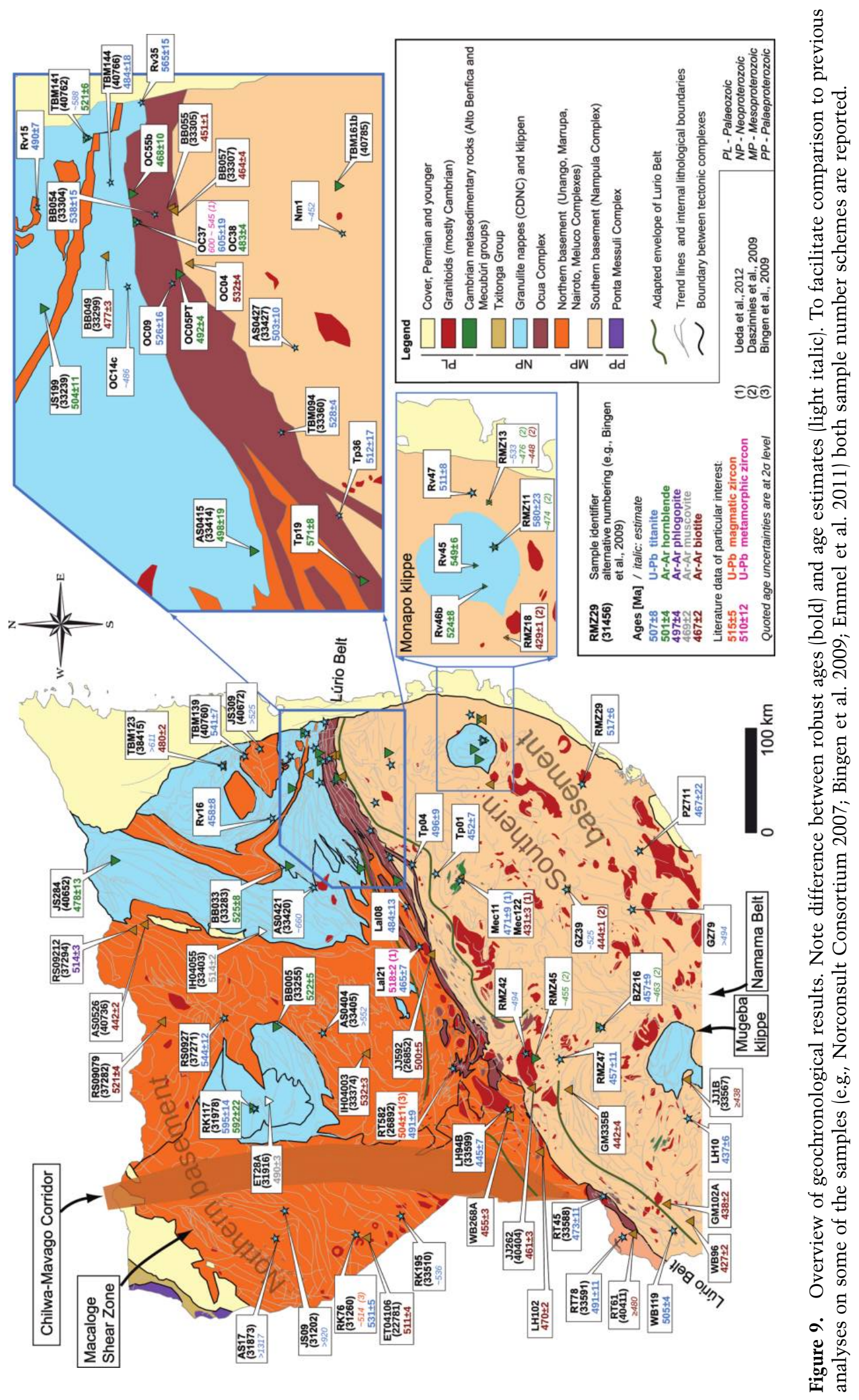


dates refer to concordia ages where available or regression ages otherwise. Estimates are based on regressions (unless otherwise noted) and represent either central reference chords or estimated lower age limits. Only robust dates are used in the subsequent probability density and cooling path calculations. A summary of the dates and estimates is given in table 1 and a description of the analyses with a discussion of their significance can be found in appendix B.

From a total of nine analyzed samples from the northern basement, four yielded robust dates and five were age estimates. Two samples from the northwest Unango Complex (JS09 and AS17), west of the Chilwa-Mavago Corridor, are distinctly older than the majority of ages from this study (fig. 9). The area is dissected by complex, anastomosing shear zone sets, and estimated lower age limits of $>920 \mathrm{Ma}$ (JS09) and >1317 Ma (AS17), respectively, were obtained from shear-bounded blocks. Three $\mathrm{U}-\mathrm{Pb}$ titanite dates from the northern basement complexes (samples RK76, RS0927, TBM139) range from $544 \pm 12$ to $531 \pm 5 \mathrm{Ma}$, with three samples (AS0404, JS309, RK195) yielding estimates of ca. 550 , ca. 535, and $>525 \mathrm{Ma}$ (figs. 5, 6; table 1). One younger date (Rv15) of $490 \pm 7 \mathrm{Ma}$ comes from the Meluco Complex, in close proximity to the Lúrio Belt (fig. 9).

In the southern basement, eight robust dates (samples AS0427, BZ216, LH10, PZ711, RMZ29, $\mathrm{RMZ47,} \operatorname{Rv} 47, \mathrm{Tp} 01)$ span a range of $517 \pm 6$ to $437 \pm 6 \mathrm{Ma}$. Four estimates span a similar age range of ca. 535 to ca. $450 \mathrm{Ma}$ (samples GZ39, GZ79, Nm1, RMZ13). The youngest of these samples (LH10) is located in the southwesternmost part of the study area (fig. 9), neighboring the Mugeba klippen and the Alto Benfica Group.

Fourteen analyses from the Lúrio Belt yielded 13 dates between $605 \pm 19$ and $445 \pm 7 \mathrm{Ma}$. The oldest ages were found in the narrow, well-defined eastern segment of the belt (fig. 9), with four samples (BB054, Oc09, TBM094, Tp36) dated between $538 \pm 15$ and $512 \pm 17 \mathrm{Ma}$, with an additional older date of $605 \pm 19 \mathrm{Ma}$ (sample Oc37). In the central and western segments of the Lúrio Belt, the dates are younger, ranging from $505 \pm 4$ to $445 \pm$ 7 Ma (samples Lal08, Lal21, LH94B, RT45, RT78, RT582, WB119). The youngest of these (LH94B) comes from the most ill-defined part of the Lúrio Belt where it appears to have been overfolded (Viola et al. 2008; Ueda et al. 2012). One additional sample (RMZ42) in the vicinity, arguably within the structural envelope of the Lúrio Belt, yielded an estimated age of ca. $494 \mathrm{Ma}$ (fig. 9).

Analyses from the CDNC gave three dates be- tween $565 \pm 15$ and $458 \pm 8 \mathrm{Ma}$ (samples Rv16, Rv35, TBM144) and one estimated reference chord of ca. $485 \mathrm{Ma}$ (sample Oc14c; fig. 9). Three samples (AS0421, TBM123, TBM141) with complex data point distributions yielded high estimates of lower age bounds of ca. 660, 610, and $590 \mathrm{Ma}$, indicating the possible presence of older grain components. One date each was obtained from the klippen north (595 $\pm 14 \mathrm{Ma}$; sample RK117) and south of the Lúrio Belt $(580 \pm 23 \mathrm{Ma}$, Monapo klippen; sample RMZ11) (fig. 9).

${ }^{40} \mathrm{Ar} /{ }^{39} \mathrm{Ar}$ Hornblende Data. The distribution of hornblende dates is strongly influenced by quality restrictions in the sample selection. Previous studies in this region have experienced considerable difficulties in obtaining simple, undisturbed ${ }^{40} \mathrm{Ar} /{ }^{39} \mathrm{Ar}$ ages from gneissic basement terranes (e.g., Jamal 2005; Rossetti et al. 2008; Daszinnies et al. 2009). In this study, after binocular microscope examination, no hornblende samples collected from the northern basement and only one sample (TBM161b) from the southern basement were found to be suitable, because of frequent intergrowth with biotite and incipient chloritization, which could have produced mixed ages and irradiation-induced ${ }^{39} \mathrm{Ar}$ and ${ }^{37} \mathrm{Ar}$ recoil artifacts. Thirteen of the 14 samples yielded dates, while no information could be obtained from the sample from the southern basement (fig. 7; table 2). Twelve samples yielded plateau ages, which were corroborated by inverse isochrons and atmospheric ${ }^{40} \mathrm{Ar} /{ }^{36} \mathrm{Ar}$ intercepts (table 2). One sample (JS199) exhibited an ${ }^{40} \mathrm{Ar} /{ }^{36} \mathrm{Ar}$ intercept significantly higher $(358 \pm 42)$ than the atmospheric ratio and, therefore, we used the inverse isochron age for this sample, as this approach accounts for nonatmospheric ${ }^{40} \mathrm{Ar} /{ }^{36} \mathrm{Ar}$ initial composition in the final age calculation (fig. 7; table 2). Four samples from the eastern Lúrio Belt (OC05PT, OC38, OC55b, Tp19) gave an age range between $571 \pm 8$ and $468 \pm 10 \mathrm{Ma}$, with three samples (OC05PT, OC38, OC55b) falling closely between $492 \pm 4$ and $468 \pm 10 \mathrm{Ma}$ (fig. 9). Five dates from the CDNC (samples AS0415, BB033, JS199, JS284, TBM144) range from $525 \pm 8$ Ma to $478 \pm$ $13 \mathrm{Ma}$. The youngest sample (JS284) comes from the northernmost part of the CDNC, while the remainder yielded dates between $525 \pm 8$ and $498 \pm 19 \mathrm{Ma}$, and originate from the south (fig. 9). Two samples from the northern klippen (RK117, BB005) yielded dates of $592 \pm 22$ and $522 \pm 5 \mathrm{Ma}$, overlapping in range with two dates from the southern Monapo klippen (samples Rv45, Rv46b) of $549 \pm 6$ and $524 \pm 8 \mathrm{Ma}$ (fig. 9).

${ }^{40} \mathrm{Ar} /{ }^{39} \mathrm{Ar}$ Biotite, Phlogopite, and Muscovite Data. Nineteen biotite samples yielded 16 plateau ages 
(fig. 8; table 2). Inverse isochrons of these samples either are poorly defined due to a predominance of radiogenic ${ }^{40} \mathrm{Ar}$ in the sample or corroborate plateau ages with atmospheric ${ }^{40} \mathrm{Ar} /{ }^{36} \mathrm{Ar}$ ratio intercepts. Three samples (GM335B, JJ1B, RT61) yielded no plateau ages; of these, one sample (GM335) had a statistically acceptable inverse isochron age and an initial ${ }^{40} \mathrm{Ar} /{ }^{36} \mathrm{Ar}$ ratio matching atmospheric argon. Two samples (JJ1B, RT61) are reported as estimates only.

Three samples (ET04106, IH04003, RS09079) from the northern basement (Unango and Marrupa complexes; fig. 4; table 2) yielded ${ }^{40} \mathrm{Ar} /{ }^{39} \mathrm{Ar}$ biotite dates from $532 \pm 3$ to $511 \pm 4 \mathrm{Ma}$. One sample that lies at the highly sheared boundary between the northern basement (Marrupa Complex) and the CDNC (Xixiano Complex) yielded an age of $442 \pm 2 \mathrm{Ma}$ (sample AS0526). Furthermore, one ${ }^{40} \mathrm{Ar} /{ }^{39} \mathrm{Ar}$ phlogopite sample (RS09212) yielded a date of $514 \pm 3 \mathrm{Ma}$.

In the southern basement, three samples (GM102A, GM335B, WB96) from the western region gave ages between $442 \pm 4$ and $427 \pm 2 \mathrm{Ma}$; one sample (JJ1B) yielded an estimated minimum age of ca. $440 \mathrm{Ma}$; and another sample, from the northeast part of the Nampula Complex (Oc04), gave a date of $532 \pm 4 \mathrm{Ma}$ (fig. 9). However, due to the immediate proximity to the Lúrio Belt, the representativeness of the latter date is doubtful.

Six samples from the Lúrio Belt (BB055, BB057, JJ262, JJ592, LH102, WB268A) gave a range of dates from $500 \pm 5$ to $451 \pm 1 \mathrm{Ma}$. One additional sample (RT61) yielded an estimated minimum age of ca. $480 \mathrm{Ma}$. Unlike the U-Pb titanite data, there were no apparent age trends along the belt (fig. 9).

The CDNC yielded two ${ }^{40} \mathrm{Ar} /{ }^{39} \mathrm{Ar}$ biotite dates (samples TBM123, BB049) of $480 \pm 2$ and $477 \pm$ $3 \mathrm{Ma}$ and one ${ }^{40} \mathrm{Ar} /{ }^{39} \mathrm{Ar}$ muscovite date (sample IH04055) of $514 \pm 2 \mathrm{Ma}$. One sample (ET28A) from the northern klippen gave a muscovite date of $490 \pm 3 \mathrm{Ma}$ (fig. 9).

\section{Age Patterns and Cooling Path Constraints}

All the studied geochronological systems record younger ages south of the Lúrio Belt compared to the north. The youngest titanite date (Rv15) in the northern basement is $490 \pm 7 \mathrm{Ma}$, and contrasts with a youngest age of $437 \pm 6 \mathrm{Ma}$ in the southern basement (sample LH10). The oldest ${ }^{40} \mathrm{Ar} /{ }^{39} \mathrm{Ar}$ hornblende age from all samples (including CDNC and klippen) north of the Lúrio Belt is $592 \pm 22 \mathrm{Ma}$ (sample RK117), contrasting with an age of $549 \pm$ $6 \mathrm{Ma}$ to the south (sample Rv45). The youngest hornblende age in the north is $478 \pm 13 \mathrm{Ma}$ (sample
JS284) and contrasts with an age of $455 \pm 3 \mathrm{Ma}$ (sample RMZ45; Daszinnies et al. 2009) in the south (fig. 4; including four dates from Daszinnies et al. 2009).

The youngest mica sample in the northern basement (ET04106), excluding one shear zone sample (AS0526), has an age of $511 \pm 4 \mathrm{Ma}$, while even the oldest age of $448 \pm 2$ (sample RMZ13; Daszinnies et al. 2009) Ma from the southern basement is younger (excluding one sample from a potential tectonic sliver related to the Lúrio Belt and including four dates from Daszinnies et al. 2009 and Ueda et al. 2012). The youngest sample in the south (from the far southwest) has an age of $427 \pm 2 \mathrm{Ma}$ and was collected from the same area as the youngest titanite sample $(437 \pm 6 \mathrm{Ma})$.

Within the Lúrio Belt, the U-Pb titanite data shows an age difference of $>25 \mathrm{Ma}$ between the older eastern part and the younger central and western regions. In contrast, no systematic difference could be established between the ${ }^{40} \mathrm{Ar} /{ }^{39} \mathrm{Ar}$ biotite data from the different parts of the belt (fig. 9).

The data can be illustrated more completely with probability density plots. This process eliminates the need to discount analytically good data that lie outside the major age clusters. Figure 10 shows probability density distribution plots for data, including $\mathrm{U}-\mathrm{Pb}$ zircon data, from this and previous studies. While the data sets from north and south of the Lúrio Belt overlap in each system and span a considerable age range, they consistently show younger components in the southern basement compared to ages in the north. In addition, they display age signatures (median) for the Lúrio Belt (cumulated) and the CNDC that are intermediate between the two basement blocks (fig. 10).

Figure 11 shows a projection of probabilities for different chronometers in a time-temperature diagram based on the assumption of simple (iso)thermal closure. Their constructed connection through temperature steps provides cooling paths for the northern and southern basement that reflect both the internal uncertainties of the dates and their external distribution. Although individual data points overlap between the north and south cooling paths, their medians are significantly different. It is generally clear that isotopic closure for each chronometer occurred earlier in the northern basement than in the southern basement. The age difference between north and south was estimated as ca. $30-70 \mathrm{Ma}$, persisting from U-Pb metamorphic zircon to ${ }^{40} \mathrm{Ar} /{ }^{39} \mathrm{Ar}$ biotite closure temperatures, and arguably increasing. A linear cooling rate of $7^{\circ}-$ $8^{\circ} \mathrm{C} / \mathrm{Ma}$ is a good gross estimate of cooling for the southern basement between ca. $900^{\circ}$ and $310^{\circ} \mathrm{C}$, 

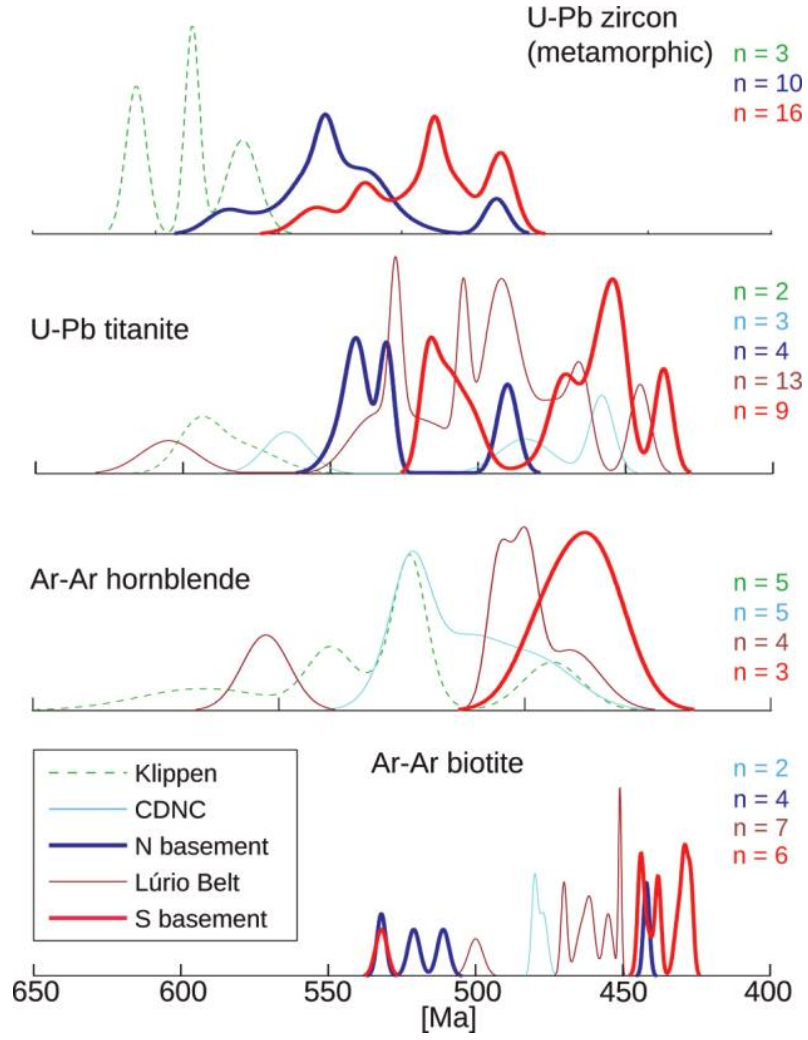

Figure 10. Probability density distribution plots for different chronometers. For each temperature step, the results are grouped by tectonic block. The median values (50-quantiles) and youngest records in the southern basement are consistently younger than those in the northern basement. Additional data from Kröner et al. (1997), Engvik et al. (2007), Grantham et al. (2008), Jacobs et al. (2008), Viola et al. (2008), Daszinnies et al. (2009), Macey et al. (2010), Thomas et al. (2010), and Ueda et al. (2012). $\mathrm{CDNC}=$ Cabo Delgado Nappe Complex.

while cooling appears to gradually slow down towards the biotite closure temperature. For the northern basement, a simple linear cooling from zircon to biotite closure temperature yielded a cooling rate of ca. $16^{\circ} \mathrm{C} / \mathrm{Ma}$. These cooling rate estimates and measured grain sizes (see app. B) were used to iteratively recalculate new closure temperatures (table 3). There was no significant difference in the recalculated closure temperature ranges between north and south despite different cooling rates and variable grain sizes; therefore, a major contribution of these factors influencing the apparent differential cooling can be excluded. The calculated cooling rates suggest that cooling in the northern basement was initiated earlier (at ca. 550 $\mathrm{Ma}$ ) and at a higher rate, while the cooling in the southern basement commenced later (at ca. 515 $\mathrm{Ma}$ ) and at a lower rate. Cooling in both blocks apparently slowed down at ca. $300^{\circ} \mathrm{C}$, but the timing difference did not diminish (fig. 11).

\section{Regional Implications and Discussion}

Delineation of Tectonic Units. The thermal histories of the tectonic units in this study are notably different and these differences broadly correlate with the established major geological boundaries. The current body of data (this study; Engvik et al. 2007; Grantham et al. 2008; Jacobs et al. 2008; Viola et al. 2008; Bingen et al. 2009; Daszinnies et al. 2009; Macey et al. 2010; Thomas et al. 2010; Ueda et al. 2012) suggests that the Lúrio Belt represents a major boundary zone between blocks with different thermal histories. The data show differences over several tens of $\mathrm{Ma}$, and with a time offset of 50-75 Ma or more, that persisted during cooling over several hundreds of degrees. The eastern Lúrio Belt yielded dates that are consistent with thermal

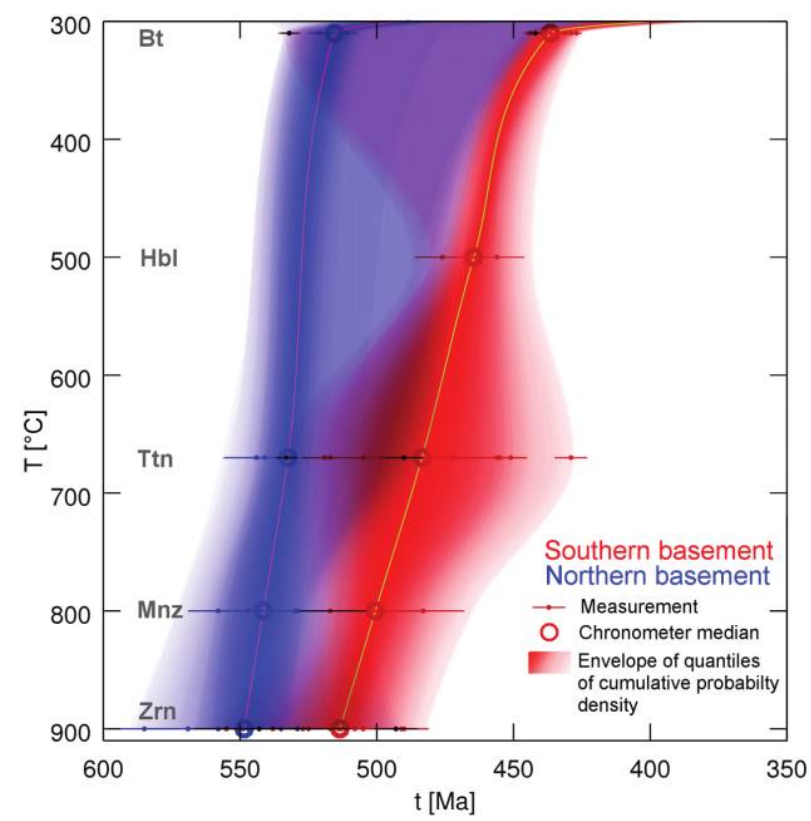

Figure 11. Post-900 Ma time-temperature trajectories constructed from quantiles of cumulative probability density. Comparison of northern and southern basements. Probabilities along each temperature line correspond to density distribution in figure 9 . Note single ${ }^{40} \mathrm{Ar} /{ }^{39} \mathrm{Ar}$ biotite measurement "outliers." Simple linear cooling rate estimates, obtained from a least squares regression line fit through $\mathrm{U}-\mathrm{Pb}$ zircon to ${ }^{40} \mathrm{Ar} /{ }^{39} \mathrm{~A}$ biotite system medians, yield ca. $16^{\circ} \mathrm{C} / \mathrm{Ma}$ for the northern basement and ca. $7^{\circ}-$ $8^{\circ} \mathrm{C} / \mathrm{Ma}$ for the southern basement. Data sources as for figure 10. The trend toward lower temperatures was constructed using fission-track data obtained from Emmel et al. (2011). 
Table 3. Calculated Closure Temperature Ranges

\begin{tabular}{|c|c|c|c|}
\hline System & $\begin{array}{c}d \mathrm{~T} / d t \\
\left({ }^{\circ} \mathrm{C} / \mathrm{Ma}\right)\end{array}$ & $\begin{array}{l}\text { Grain size } \\
\qquad(\mu \mathrm{m})\end{array}$ & $\begin{array}{c}\text { Closure temperature } \\
T_{\mathrm{C}}\left({ }^{\circ} \mathrm{C}\right)\end{array}$ \\
\hline \multicolumn{4}{|c|}{ North of Lúrio Belt: } \\
\hline Titanite & 16 & $75-300$ & $577 \pm 41$ to $629 \pm 46$ \\
\hline Hornblende ${ }^{a}$ & 16 & $100-300$ & $494 \pm 37$ to $535 \pm 40$ \\
\hline Phlogopite & 16 & 1000 & $452 \pm 46$ \\
\hline Muscovite ${ }^{\mathrm{a}}$ & 16 & $550-750$ & $441 \pm 94$ to $450 \pm 96$ \\
\hline Biotite & 16 & $250-800$ & $314 \pm 29$ to $348 \pm 31$ \\
\hline \multicolumn{4}{|c|}{ South of Lúrio Belt: } \\
\hline Titanite & 7.5 & $75-300$ & $564 \pm 41$ to $615 \pm 44$ \\
\hline Hornblende $^{a}$ & 7.5 & $100-300$ & $481 \pm 36$ to $520 \pm 39$ \\
\hline Biotite & 7.5 & $400-2000$ & $316 \pm 29$ to $364 \pm 33$ \\
\hline \multicolumn{4}{|l|}{ Lúrio Belt: ${ }^{b}$} \\
\hline Titanite & $\sim 10$ & $75-500$ & $569 \pm 41$ to $640 \pm 47$ \\
\hline Hornblende & $\sim 10$ & $100-400$ & $486 \pm 36$ to $536 \pm 41$ \\
\hline Biotite & $\sim 10$ & $400-2000$ & $320 \pm 29$ to $369 \pm 33$ \\
\hline
\end{tabular}

Note. Nominal closure temperatures calculated for simple closure (Dodson 1973) based on experimentally determined diffusion parameters (titanite: Cherniak 1993; hornblende: Harrison 1981; phlogopite: Giletti 1974; muscovite, for 5 kbar: Harrison et al. 2009; biotite: Grove and Harrison 1996). Errors for activation energy (dominant) and frequency factor are included as reported, and a logarithmic error of factor 2 is adapted for grain sizes and cooling rates. $T_{\mathrm{c}}$ for titanite from experimental data appears to be low $(\mathrm{cf}$. Scott and St. Onge 1995).

a Cooling rates of the basement are used as approximation for nappe rocks.

b Cooling rates are approximated from northern and southern basements.

histories cooling from granulite-facies metamorphism (>570 Ma), with subsequent amphibolite facies metamorphism occurring around 560-550 Ma (Engvik et al. 2007; Ueda et al. 2012). Our data corroborate late high-temperature metamorphic conditions at or after ca. $515 \mathrm{Ma}$ (possibly starting at 540-530 Ma; Viola et al. 2008) in the central and western belts, which were associated with granitoid intrusions and with additional deformation (Bingen et al. 2009; Ueda et al. 2012). The data from the geochronometers presented here probably reflect continued slow cooling from these conditions until ca. $440 \mathrm{Ma}$ (fig. 11).

Data from the granulite-facies klippen on both sides of the Lúrio Belt are similar to each other and to data from the main CDNC exposure (fig. 9). They are also consistent with reported igneous and metamorphic ages from the southern klippen (Kröner et al. 1997; Grantham et al. 2008), suggesting that they are remnants of the same granulite-facies nappe complex that may have continued northward into the Eastern Granulites in Tanzania (e.g., Coolen et al. 1982; Fritz et al. 2005) and southward (within a reconstructed Gondwana) into the Schirmacher Oasis in East Antarctica (Baba et al. 2010). A group of younger $(<490 \mathrm{Ma}) \mathrm{U}-\mathrm{Pb}$ and ${ }^{40} \mathrm{Ar} /{ }^{39} \mathrm{Ar}$ ages in the CDNC is not well understood and may indicate limited reactivation of collisional structures, for example, during extension.

Stenian, Late Ediacaran, and Cambro-Ordovician Metamorphism. The spatial and temporal distri- bution of the data presented here show three major phases of metamorphism and subsequent cooling, termed $\mathrm{M}_{1}, \mathrm{M}_{2}$, and $\mathrm{M}_{3}$ (see table 1 in Ueda et al. 2012 for comparison of deformational and metamorphic episodes in northern Mozambique with other authors). Traces of Stenian (>950 Ma) metamorphism, $M_{1}$, are present only in the northwest part of the area. This is equivalent to the late stages of regional high-grade metamorphism recognized in the Unango Complex, associated with Mesoproterozoic orogenesis (Bingen et al. 2009).

Our data reveal the waning effects of the late Ediacaran metamorphism $M_{2}$ associated with collisional orogeny and the amalgamation of Gondwana and replicates high-grade conditions in the period $>600$ to $550 \mathrm{Ma}$. This polyphase metamorphic phase, $M_{2}$, can probably be further subdivided into a precollision metamorphism $\left(\mathrm{M}_{2 \mathrm{a} \prime}>570 \mathrm{Ma}\right)$ apparently restricted to the hanging wall zone of the EAAO (nappes-klippen and CDNC) and a more widespread collision metamorphism $\left(\mathrm{M}_{2 \mathrm{~b}}\right.$, ca. 550 $\mathrm{Ma}$ ) recorded in the basement footwall (cf. Cutten et al. 2006). In the southern basement, $M_{2 b}$ was probably obliterated by an early Paleozoic postcollisional metamorphic event, $M_{3}$, which occurred between ca. 525 and $440 \mathrm{Ma}$.

The oldest $>920 \mathrm{Ma}$ U-Pb zircon (Bingen et al. 2009) and titanite ages (this study) from the extreme northwest part of the investigated area signify rocks that escaped the high-grade metamorphism during Ediacaran and subsequent times. In 
this northwest region, deformation associated with greenschist facies metamorphism took place along discrete shear zones (Pinna et al. 1993; Bingen et al. 2009; Boyd et al. 2010), and this area is consequently regarded as forming the foreland of the EAAO. Following Pinna et al. (1993), we interpret the Chilwa-Mavago Corridor in the northwest part of the northern basement as a zone of thrusting at the western margin of the EAAO that possibly linked up with thrusts in southern Tanzania (e.g., Cutten et al. 2006).

However, titanite growth or cooling from an earlier event is hinted at by the results from sample AS17, with an estimated age of ca. 1330-1310-Ma that apparently was not reset during the ca. $950 \mathrm{Ma}$ $M_{1}$ metamorphism. In support of this, it is noteworthy that as yet unidentified sources of 1350$1300 \mathrm{Ma}$ crust have been observed in detrital zircons in the metasedimentary rocks of the Late Neoproterozoic to Early Cambrian Alto Benfica Group (Thomas et al. 2010), and xenocrystic zircons of similar age are reported in southernmost Tanzania, where the juvenile character of the Late Mesoproterozoic gneisses is disputed (Kröner et al. 2003).

Differential Cooling and the Delamination Model. The northern and southern basement blocks of northeast Mozambique have undergone different metamorphic and cooling histories (fig. 11). This is shown in three time slice-temperature maps of northeast Mozambique (fig. 12). These different histories can possibly be explained in two ways. One possible cause for the observed thermal offset is static thermal maturation of a thickened crust in which high temperatures were created and maintained from $>550 \mathrm{Ma}$ until ca. $515 \mathrm{Ma}$, but deeper crustal levels were then exposed in the south (e.g., Grantham et al. 2008). The other possibility is to invoke a separate later metamorphic event largely confined to the southern basement. There is conclusive evidence in support of a young metamorphic event $\left(M_{3}\right)$ in the south, in the recent identification of a sequence of clastic metasedimentary rocks, the Mecubúri Group, which were deposited unconformably on the exhumed Mesoproterozoic southern basement at ca. $530 \mathrm{Ma}$. Both sediments and basement were later subjected to HT-LP, sillimanite grade metamorphism and migmatization (Thomas et al. 2010). The metasediments mark an exhumed Cambrian surface of the basement between $M_{2}$ and $M_{3}$ and demonstrate that high temperatures cannot have been statically maintained after collision. This implies that the voluminous granitoids that accompany migmatization in the Mecubúri Group and the southern basement (e.g., fig. 3) are not due to self-sustained lower crustal melting after a $>550 \mathrm{Ma}$ collision event (cf. Grantham et al. 2008). The Mecubúri Group and the Lúrio Belt in particular, but also the southern basement, show intense postcollisional $\mathrm{D}_{3}$ deformation that locally obliterated earlier $\mathrm{D}_{2 \mathrm{~b}}$ collision-related fabrics. This clearly indicates thermotectonic activity in a separate younger tectonic regime, which was unrelated to the earlier $\mathrm{D}_{2}$ collision (Ueda et al. 2012).

The observations in the southern basement and Lúrio Belt of separate young $\mathrm{M}_{3}$ HT-metamorphism, migmatization, and granitoid-charnockite magmatism require additional heat sources capable of delaying cooling with respect to the northern basement. These features are consistent with a significant and persistent increase in heat flow in the south, probably originating from a deep-seated source. Lithosphere delamination under the Nampula Complex, rolling back from the Lúrio Belt dis-
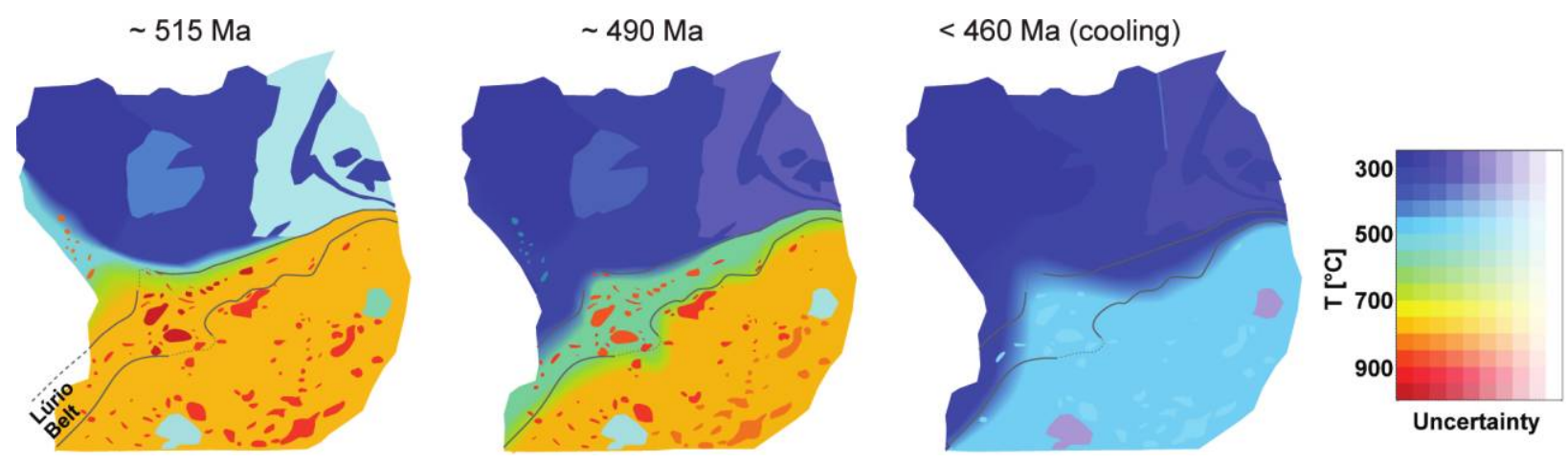

Figure 12. Interpretative representation of metamorphism, granitoid magmatism, and cooling at different times over northeast Mozambique. The color tone denotes temperature, while the ink strength denotes higher certainty (qualitative strength of constraint). The figure was compiled from geological/petrological constraints (see "Geological Background"), time-temperature trajectories (fig. 11) and map data. 
continuity (fig. 13), represents a potential explanation for renewed tectonic activity, basal heating, and HT/LP metamorphism and magmatism, and it could have maintained an elevated heat flow (Ueda et al. 2012). The different cooling rates between the northern and southern basements (fig. 11), with a possible relative slowdown of postorogenic cooling between peak conditions and ca. $500^{\circ} \mathrm{C}$ in the south, can be explained in terms of cooling in the southern basement being arrested by sustained high heat flow from ascending hot asthenosphere. The new data are consistent with a partial delamination hypothesis, thermally untying delaminated (southern basement) and undelaminated (northern basement) segments of the EAAO in northeast Mozambique.

Other Models: Regional Implications. We have proposed a model of lithosphere delamination to explain the observed tectonothermal evolution of the crust in northeast Mozambique (see also Ueda et al. 2012). However, other possibilities may be invoked to explain the observed geology and these are discussed below.

A Younger Collision. Our data do not support the model of the superposition of two spatially separate major, continental-scale orogenies in northeast Mozambique to account for the proposed intersection of the broadly north- (EAAO) and west-trending ("Kuunga" s.l.) orogenic systems (Meert 2003; Collins and Pisarevsky 2005), other than that the Lúrio Belt represents a long-lived major east-northeast-trending crustal discontinuity. $\mathrm{M}_{2 \mathrm{~b}}$ ages in the Lúrio Belt are generally compatible with ca. 530-510-Ma ages to the west, in the Zambesi-Lufilian Arc-Southern Irumide Belt systems (Vinyu et al. 1999; John et al. 2004; Johnson et al. 2005) and the east (in a Gondwana reconstruction) in the Prydz Bay-Prince Charles mountains (Antarctica) enclaves (Boger et al. 2002; Corvino et al. 2008; Liu et al. 2009). However, older $M_{2 a}$-type ages (>600-570 Ma; cf. Grantham et al. 2008) have now been confirmed in the southern Monapo klippen, suggesting that the (nappes complexes) extended over both sides of the Lúrio Belt (see above). Lateral differences in HT cooling along the Lúrio Belt would imply considerable diachronism of a potential collision and thus challenge large-scale correlations based on a similarity of ages further east and west. The collision would need to be concluded by ca. 525-515 Ma (Mecubúri Group provenance and granitoid intrusion age in Lúrio Belt; Thomas et al. 2010; Ueda et al. 2012), while the thermal offset between the blocks increases until ca. 440 Ma. The bulk of the granitoids in the southern base-
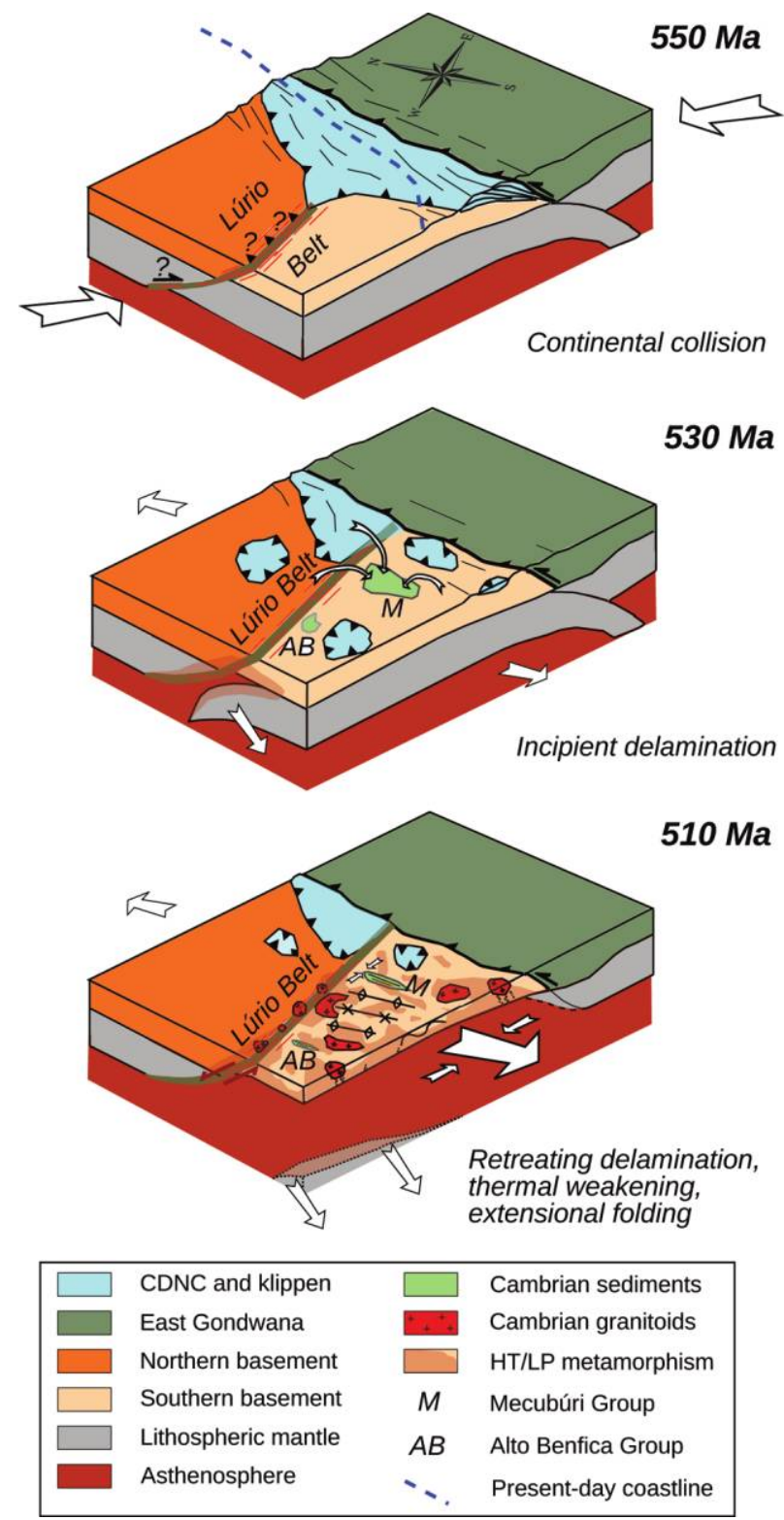

Figure 13. Schematic block diagrams showing the evolution of the East African-Antarctic Orogen in northeast Mozambique. The northern and southern basements are part of West Gondwana. Oblique collision with East Gondwana culminated at $550 \mathrm{Ma}$, emplacing nappes with granulite-facies rocks in a northwesterly direction. The onset of extensional collapse between ca. 540 and $530 \mathrm{Ma}$ exhumed the southern basement and led to deposition of the Mecubúri and Alto Benfica groups in restricted (Cambrian) sedimentary basins. High-temperature-low-pressure (HTLP) metamorphism, voluminous granitoid magmatism, and coeval extensional shear along the Lúrio Belt at or slightly before ca. 510 Ma probably dates culmination of thermal and mechanical response to delamination. The Lúrio Belt underwent protracted activity, although the kinematics have not been fully resolved kinematics (red lines show general activity). 
ment is coeval to or postdate the hypothetical second collision (Grantham et al. 2008; Jacobs et al. 2008; Bingen et al. 2009; Macey et al. 2010), leaving little time for a hypothetical second thermal maturation phase following a Kuunga closure.

Given the above arguments, the low-pressure character of the late $\left(M_{3}\right)$ metamorphism, and the perpendicular orientation of the late northwesttrending $\mathrm{D}_{3}$ structures (including crustal-scale folds) to its postulated suture (Ueda et al. 2012), a major continental-scale collision event at ca. 525 $\mathrm{Ma}$ (Kuunga Orogen) seems implausible. Instead, it is suggested that all observations are related to a complex series of events that took place within one single major orogenic cycle (EAAO), including early metamorphism experienced by outboard terranes ( $>570 \mathrm{Ma})$, widespread collision-related metamorphism (at ca. $550 \mathrm{Ma}$ ), and finally a polyphase and protracted extensional collapse stage in the southern basement (fig. 13).

Potential Contribution of Differential Exhumation Levels. Throughout northeast Mozambique, differences in the timing of cooling are shown by several chronometers (figs. 9-11). The initial age differences between the northern and southern basement remain stable or increase during postcollisional cooling from ca. $550 \mathrm{Ma}$ onward (fig. 11). A further-reaching consideration of these observations, in addition to the thermal effects of $M_{3}$ and delamination, is that the relative cooling pattern was modified by different exhumation levels, caused for example by increased local uplift during prolonged collapse or even by far later Gondwana rifting and breakup (e.g., Emmel et al. 2011). However, the Mecubúri Group metasediments clearly mark a post$\mathrm{D}_{2}$ (postcollisional) paleo-surface of the Nampula Complex (figs. 2, 13), severely limiting the possible effects of vertical offsets on the cooling ages.

\section{Conclusions}

High-grade metamorphism and cooling from high to intermediate temperatures in northeast Mozambique were complex and polyphase and overlap in both temporal and spatial distribution. The following phases were recognized in the various crustal blocks:

1. Old Stenian (>950 Ma) $M_{1}$ metamorphism in the northwest northern basement probably marks a drop in metamorphic grade across the orogenic front that coincides with the Chilwa-Mavago Corridor. This event corresponds to the Mesoproterozoic orogeny in the Unango Complex. There may be a previously unrecognized older crustal com- ponent to the Unango Complex, as hinted at by one $\mathrm{U}-\mathrm{Pb}$ titanite age estimate of ca. $1300 \mathrm{Ma}$.

2. Early Ediacaran (>570 Ma) collision-related $\mathrm{M}_{2 \mathrm{a}}$ metamorphism was recorded only in high-strain rocks that underwent granulite-facies metamorphism (CDNC, klippen, and Lúrio Belt).

3. Ca. $550 \mathrm{Ma} \mathrm{M}_{2 \mathrm{~b}}$ metamorphism was related to collision and subsequent cooling through intermediate temperatures between ca. 535 and $520 \mathrm{Ma}$, but a 30-50-Ma offset in cooling developed in the southern basement. The deposition of the Mecubúri Group metasediments on exhumed southern basement at ca. $530 \mathrm{Ma}$ indicates the termination of collision and subsequent extension.

4. A protracted younger phase of HT metamorphism $\left(\mathrm{M}_{3}\right)$ between ca. 515-460 Ma and delayed cooling until ca. $440 \mathrm{Ma}$ affected only the southern basement (Nampula Complex) and the Lúrio Belt.

Postcollisional HT/LP metamorphism, local intense migmatization, granitoid magmatism, polyphase deformation, and slower postcollisional cooling in the southern basement require a source of elevated heat flow and stress change restricted to this crustal block. These observations are compatible with a process of lithosphere delamination and subsequent extensional collapse. However, these observations are less compatible with a model where the younger ages represent a major "Kuunga"-type collision orogen and closure along the Lúrio Belt. The preservation of Cambrian metasediments to the south precludes an explanation of different cooling histories by late differential exhumation in post-Gondwana times.

\section{A C K N O W L E D G M E N T S}

The research was supported by Norwegian Research Council (NFR) grant 177514 to J. Jacobs and by British Geological Survey (BGS) funds. R. J. Thomas and M. S. A. Horstwood publish with the approval of the executive director, BGS-Natural Environment Research Council. B. Turrin and C. Swisher are thanked for Ar-Ar analyses at Rutgers, anda R. Kumar for mineral separation. Extensive SEM and BSE studies at the University of Bergen were facilitated by Egil Erichsen, and LA-ICPMS analyses were assisted by O. Tumyr. Sample material was provided by the BGS, the Geological Survey of Norway (NGU), and the National Directorate of Geology (DNG), being collected by various geologists from the BGS, the NGU, the DNG, and the Council for Geoscience (CGS) during the World Bank mapping project. Discussions with B. Bingen, A. Engvik, G. Viola, and W. Nemec and an internal review by K. Goodenough have furthered the de- 
velopment of the manuscript. Two constructive reviews by F. Corfu and S. Pisarevsky are gratefully acknowledged and have positively contributed to this article.

\section{RE FER E N C ES C I T E D}

Aleinikoff, J. N.; Wintsch, R. P.; Fanning, C. M.; and Dorais, M. J. 2002. U-Pb geochronology of zircon and polygenetic titanite from the Glastonbury Complex, Connecticut, USA: an integrated SEM, EMPA, TIMS, and SHRIMP study. Chem. Geol. 188:125-147.

Baba, S.; Hokada, T.; Kaiden, H.; Dunkley, D.; Owada, M.; and Shiraishi, K. 2010. SHRIMP zircon U-Pb dating of sapphirine-bearing granulite and biotitehornblende gneiss in the Schirmacher Hills, east Antarctica: implications for Neoproterozoic ultrahightemperature metamorphism predating the assembly of Gondwana. J. Geol. 118:621-639.

Bingen, B.; Jacobs, J.; Viola, G.; Henderson, I. H. C.; Skår, Ø.; Boyd, R.; Thomas, R. J.; Solli, A.; Key, R. M.; and Daudi, E. X. F. 2009. Geochronology of the Precambrian crust in the Mozambique belt in NE Mozambique, and implications for Gondwana assembly. Precambrian Res. 170:231-255.

Boger, S. D.; Carson, C. J.; Fanning, C. M.; Hergt, J. M.; Wilson, C. J. L.; and Woodhead, J. D. 2002. Pan-African intraplate deformation in the northern Prince Charles Mountains, east Antarctica. Earth Planet. Sci. Lett. 195:195-210.

Boyd, R.; Nordgulen, Ø.; Thomas, R. J.; Bingen, B.; Bjerkgård, T.; Grenne, T.; Henderson, I.; et al. 2010. The geology and geochemistry of the east African orogen in NE Mozambique. S. Afr. J. Geol. 113:87-129.

Cadoppi, P.; Costa, M.; and Sacchi, R. 1987. A cross section of the Namama Thrust belt (Mozambique). J. Afr. Earth Sci. 6:493-504.

Cherniak, D. J. 1993. Lead diffusion in titanite and preliminary results of the effects of radiation damage on $\mathrm{Pb}$ transport. Chem. Geol. 110:177-194.

Collins, A. S., and Pisarevsky, S. A. 2005. Amalgamating eastern Gondwana: the evolution of the CircumIndian orogens. Earth Sci. Rev. 71:229-270.

Coolen, J. J. M. M. M.; Priem, H. N. A.; Verdumen, E. A. T.; and Verschure, R. H. 1982. Possible zircon U-Pb evidence of Pan-African granulite-facies metamorphism in the Mozambique belt of southern Tanzania. Precambrian Res. 17:31-40.

Corvino, A. F.; Boger, S. D.; Henjes-Kunst, F.; Wilson, C. J. L.; and Fitzsimons, I. C. W. 2008. Superimposed tectonic events at $2450 \mathrm{Ma}, 2100 \mathrm{Ma}, 900 \mathrm{Ma}$ and 500 $\mathrm{Ma}$ in the north Mawson escarpment, Antarctic Prince Charles Mountains. Precambrian Res. 167:281302.

Cutten, H.; Johnson, S. P.; and De Waele. B. 2006. Protolith ages and timing of metasomatism related to the formation of whiteschist at Mautia Hill, Tanzania: implications for the timing of assembly of Gondwana. J. Geol. 114:683-698.

Daszinnies, M. C.; Jacobs, J.; Wartho, J. A.; and Grantham, G. H. 2009. Post Pan-African thermo-tectonic evolution of the north Mozambican basement and its implication for the Gondwana rifting. Inferences from ${ }^{40} \mathrm{Ar} /{ }^{39} \mathrm{Ar}$ hornblende, biotite and titanite fission-track dating. In Lisker, F.; Ventura, B.; and Glasmacher, U., eds. Thermochronological methods: from palaeotemperature constraints to landscape evolution model. Geol. Soc. Lond. Spec. Publ. 324:317-330.

Dodson, M. H. 1973. Closure temperature in cooling geochronological and petrological systems. Contrib. Mineral. Petrol. 40:259-274.

Emmel, B.; Kumar, R.; Ueda, K.; Jacobs, J.; Daszinnies, M. C.; Thomas, R. J.; and Matola, R. 2011. Thermochronological history of an orogen-passive margin system: an example from northern Mozambique. Tectonics 30:TC2002, doi:10.1029/2010TC002714.

Engvik, A. K.; Tveten, E.; Bingen, B.; Viola, G.; Erambert, M.; Feitio, P.; and de Azavedo, S. 2007. P-T-t evolution and decompression textures of Pan-African high-pressure granulites, Lúrio Belt, northeastern Mozambique. J. Metamorph. Geol. 25:935-952.

Fritz, H.; Tenczer, V.; Hauzenberger, C. A.; Wallbrecher, E.; Hoinkes, G.; Muhongo, S.; and Mogessie, A. 2005. Central Tanzanian tectonic map: a step forward to decipher Proterozoic structural events in the east African orogen. Tectonics 24:TC6013, doi:10.1029/ 2005 TC001796.

Frost, R. B.; Chamberlain, K. R.; and Schumacher, J. C. 2001. Sphene (titanite): phase relations and role as a geochronometer. Chem. Geol. 172:131-148.

Giletti, B. J. 1974. Studies in diffusion I: argon in phlogopite mica. In Hoffman, A. W.; Giletti, B. J.; Yoder, H. S., Jr.; and Yung, R. A., eds. Geochemical transport and kinetics. Washington, DC, Carnegie Institution of Washington, p. 107-115.

Grantham, G. H.; Macey, P. H.; Ingram, B. A.; Roberts, M. P.; Armstrong, R. A.; Hokada, T.; Shiraishi, K.; Jackson, C.; Bisnath, A.; and Manhica, V. 2008. Terrane correlation between Antarctica, Mozambique and Sri Lanka: comparison of geochronology, lithology, structure and metamorphism and possible implications for the geology of southern Africa and Antarctica. In Satish-Kumar, M.; Motoyoshi, Y.; Osanai, Y.; Hiroi, Y.; and Shiraishi, K., eds. Geodynamic evolution of east Antarctica: a key to the east-west Gondwana connection. Geol. Soc. Lond. Spec. Publ. 308:91-119.

Grove, M., and Harrison, T. M. 1996. ${ }^{40} \mathrm{Ar}^{*}$ diffusion in Fe-rich phlogopite. Am. Mineral. 81:940-951.

Hames, W. E., and Bowring, S. A. 1994. An empirical evaluation of the argon diffusion geometry in muscovite. Earth Planet. Sci. Lett. 124:161-167.

Harrison, T. M. 1981. Diffusion of ${ }^{40} \mathrm{Ar}$ in hornblende. Contrib. Mineral. Petrol. 78:324-331.

Harrison, T. M.; Célérier, J.; Aikman, A. B.; Herman, J.; 
and Heizler, M. T. 2009. Diffusion of ${ }^{40} \mathrm{Ar}$ in muscovite. Geochim. Cosmochim. Acta 73:1039-1051.

Jacobs, J. 1999. Neoproterozoic/Lower Palaeozoic events in central Dronning Maud Land (east Antarctica). Gondwana Res. 2:473-480.

Jacobs, J.; Bauer, W.; and Fanning, C. M. 2003. Late Neoproterozoic/Early Palaeozoic events in central Dronning Maud Land and significance for the southern extension of east African orogen into east Antarctica. Precambrian Res. 126:27-53.

Jacobs, J.; Bingen, B.; Thomas, R. J.; Bauer, W.; Wingate, M.; and Feitio, P. 2008. Early Palaeozoic orogenic collapse and voluminous late-tectonic magmatism in Dronning Maud Land and Mozambique: insights into the partially delaminated orogenic root of the east African-Antarctic orogen? In Satish-Kumar, M.; Motoyoshi, Y.; Osanai, Y.; Hiroi, Y.; and Shiraishi, K., eds. Geodynamic evolution of east Antarctica: a key to the east-west Gondwana connection. Geol. Soc. Lond. Spec. Publ. 308:69-90.

Jacobs, J.; Fanning, C. M.; Henjes-Kunst, F.; Olesch, M.; and Paech, H. J. 1998. Continuation of the Mozambique belt into east Antarctica: Grenville-age metamorphism and polyphase Pan-African high-grade events in central Dronning Maud Land. J. Geol. 106: 385-406.

Jamal, D. 2005. Crustal studies across selected geotransects in NE Mozambique: differentiating between Mozambiquan ( Kibaran) and Pan African events, with implications for Gondwana studies. PhD thesis, University of Cape Town, $365 \mathrm{p}$.

John, T.; Schenk, V.; Mezger, K.; and Tembo, F. 2004. Timing and PT evolution of whiteschist metamorphism in the Lufilian Arc-Zambezi belt orogen (Zambia): implications for the assembly of Gondwana. J. Geol. 112:71-90.

Johnson, S. P.; Rivers, T.; and De Waele, B. 2005. A review of the Mesoproterozoic to early Palaeozoic magmatic and tectonothermal history of south-central Africa: implications for Rodinia and Gondwana. J. Geol. Soc. Lond. 161:433-450.

Jourde, G., and Vialette, Y. 1980. La chaîne du Lurio (nord Mozambique). Un témoin de l'existence de chaînes Kibariennes (800-1350 Ma) en Afrique Orientale. Open file report. Orleans, France, Bureau de Recherches Géologiques et Minières.

Jung, S., and Hellebrand, E. 2007. Textural, geochronological and chemical constraints from polygenetic titanite and monogenetic apatite from a mid-crustal shear zone: an integrated EPMA, SIMS, and TIMS study. Chem. Geol. 241:88-107.

Kröner, A.; Muhongo, S.; Hegner, S.; Wingate, M. T. D. 2003. Single-zircon geochronology and $\mathrm{Nd}$ isotopic systematics of Proterozoic high-grade rocks from the Mozambique belt of southern Tanzania (Masasi area): implications for Gondwana assembly. J. Geol. Soc. Lond. 160:745-757.

Kröner, A.; Sacchi, R.; Jaeckel, P.; and Costa, M. 1997. Kibaran magmatism and Pan-African granulite metamorphism in northern Mozambique: single zircon ages and regional implications. J. Afr. Earth. Sci. 25: 467-484.

Liu, X.; Zhao, Y.; Song, B.; Liu, J.; and Cui, J. 2009. SHRIMP U-Pb zircon geochronology of high-grade rocks and charnockites from the eastern Amery ice shelf and southwestern Prydz Bay, east Antarctica: constraints on late Mesoproterozoic to Cambrian tectonothermal events related to supercontinent assembly. Gondwana Res. 16:342-361.

Ludwig, K. R. 2008. Users manual for Isoplot 3.70: a geochronological toolkit for Microsoft Excel. Special Publication 4. Berkeley, CA, Berkeley Geochronology Center, $77 \mathrm{p}$.

Macey, P. H.; Ingram, B. A.; Roberts, M. R.; de Kock, G.; Cronwright, M. S.; Botha, G. A.; Grantham, G. H.; et al. 2007. Map explanation of sheets Alto Molócuè, 1537; Murrupula, 1538; Nampula, 1539; Mogincual, 1540; Errego, 1637; Gilé (1638) and Angoche (163940). Republic of Mozambique, National Directorate of Geology.

Macey, P. H.; Thomas, R. J.; Grantham, G. H.; Ingram, B. A.; Jacobs, J.; Armstrong, R. A.; Roberts, M. P.; et al. 2010. Mesoproterozoic geology of the Nampula block, northern Mozambique: tracing fragments of Mesoproterozoic crust in the heart of Gondwana. Precambrian Res. 182:124-148.

Meert, J. G. 2003. A synopsis of events related to the assembly of eastern Gondwana. Tectonophysics 362: $1-40$.

Melezhik, V. A.; Kuznetsov, A. B.; Fallick, A. F.; Smith, R. A.; Gorokhov, I. M.; Jamal, D.; and Catuane, F. 2006. Depositional environments and an apparent age for the Geci meta-limestones: constraints on the geological history of northern Mozambique. Precambrian Res. 148:19-31.

Norconsult Consortium. 2007. Mineral resources management capacity building project, Republic of Mozambique; component 2: geological infrastructure development project, geological mapping lot 1 ; sheet explanation: 32 sheets; scale $1: 250,000$, Report No. B6.f. Republic of Mozambique, National Directorate of Geology.

Pinna, P.; Jourde, G.; Calvez, J. Y.; Mroz, J. P.; and Marques, J. M. 1993. The Mozambique belt in northern Mozambique; Neoproterozoic (1100-850 Ma) crustal growth and tectogenesis, and superimposed PanAfrican (800-550 Ma) tectonism. Precambrian Res. 62: $1-59$.

Powell, C.; Li, Z. X.; McElhinny, M.; Meert, J.; and Park, J. 1993. Paleomagnetic constraints on timing of the Neoproterozoic breakup of Rodinia and the Cambrian formation of Gondwanaland. Geology 21:889-892.

Rossetti, F.; Cozzupoli, D.; and Phillips, D. 2008. Compressional reworking of the east African orogen in the Uluguru mountains of eastern Tanzania at ca. $550 \mathrm{Ma}$ : implications for the final assembly of Gondwana. Terra Nova 20:59-67.

Sacchi, R.; Marques, J. M.; Costa, M.; and Casati, C. 1984. Kibaran events in the southernmost Mozambique belt. Precambrian Res. 25:141-159. 
Scott, D. J., and St.-Onge, M. R. 1995. Constraints on Pb closure temperature in titanite based on rocks from the Ungava orogen, Canada; implications for U-Pb geochronology and P-T-t path determinations. Geology 23:1123-1126.

Shackleton, R. M. 1996. The final collision zone between east and west Gondwana: where is it? J. Afr. Earth. Sci. 23:271-287.

Stacey, J. S., and Kramers, J. D. 1975. Approximation of terrestrial lead isotope evolution by a two-stage model. Earth Planet. Sci. Lett. 26:207-221.

Stern, R. J. 1994. Arc assembly and continental collision in the Neoproterozoic east African orogen: implications for the consolidation of Gondwanaland. Annu. Rev. Earth Planet. Sci. 22:319-351.

Storey, C. D.; Smith, M. P.; and Jeffries, T. E. 2007. In situ LA-ICP-MS U-Pb dating of metavolcanics of Norrbotten, Sweden: records of extended geological histories in complex titanite grains. Chem. Geol. 240: 163-181.

Thomas, R. J.; Jacobs, J.; Horstwood, M. S. A.; Ueda, K.; Bingen, B.; and Matola, R. 2010. The Mecubúri and Alto Benfica groups, NE Mozambique: aids to unravelling ca. 1 and $0.5 \mathrm{Ga}$ events in the east African orogen. Precambrian Res. 178:72-90.

Ueda, K.; Jacobs, J.; Thomas, R. J.; Kosler, J.; Jourdan, F.; and Matola, R. 2012. Delamination-induced late tectonic deformation and high-grade metamorphism of the Proterozoic Nampula complex, northern Mozambique. Precambrian Res. 196-198:275-294.

Vinyu, M. L.; Hanson, R. E.; Martin, M. W.; Bowring, S. A.; Jelsma, H. A.; Krol, M. A.; and Dirks, P. H. G. M. 1999. U-Pb and ${ }^{40} \mathrm{Ar} /{ }^{39} \mathrm{Ar}$ geochronological constraints on the tectonic evolution of the easternmost part of the Zambezi orogenic belt, northeastern Zimbabwe. Precambrian Res. 98:67-82.

Viola, G.; Henderson, I. H. C.; Bingen, B.; Thomas, R. J.; Smethurst, M. A.; and de Azavedo, S. 2008. Growth and collapse of a deeply eroded orogen: insights from structural and geochronological constraints on the Pan-African evolution of NE Mozambique. Tectonics 27:TC5009, doi:10.1029/2008TC002284.

Willigers, B. J. A.; Baker, J. A.; Krogstad, E. J.; and Peate, D. W. 2002. Precise and accurate in situ $\mathrm{Pb}-\mathrm{Pb}$ dating of apatite, monazite, and sphene by laser ablation multiple-collector ICP-MS. Geochim. Cosmochim. Acta 66:1051-1066.

Willigers, B. J. A.; Krogstad, E. J.; and Wijbrans, J. R. 2001. Comparison of thermochronometers in a slowly cooled Granulite terrain: Nagssugtoqidian orogen, west Greenland. J. Petrol. 42:1729-1749. 